\title{
Lack of steady-state in the global biogeochemical Si cycle: emerging evidence from lake $\mathrm{Si}$ sequestration
}

\author{
Patrick J. Frings · Wim Clymans • \\ Erik Jeppesen • Torben L. Lauridsen • \\ Eric Struyf • Daniel J. Conley
}

Received: 4 September 2013/ Accepted: 17 December 2013

(C) Springer Science+Business Media Dordrecht 2014

\begin{abstract}
Weathering of silicate minerals releases dissolved silicate (DSi) to the soil-vegetation system. Accumulation and recycling of this DSi by terrestrial ecosystems creates a pool of reactive $\mathrm{Si}$ on the continents that buffers DSi export to the ocean. Human perturbations to the functioning of the buffer have been a recent research focus, yet a common assumption is that the continental Si cycle is at steadystate. However, we have no good idea of the timescales of ecosystem $\mathrm{Si}$ pool equilibration with their environments. A review of modelling and geochemical considerations suggests the modern continental $\mathrm{Si}$ cycle is in fact characterised in the longterm by an active accumulation of reactive $\mathrm{Si}$, at least partially attributable to lakes and reservoirs. These
\end{abstract}

Responsible Editor: Cory Cleveland

P. J. Frings $(\bowtie) \cdot$ W. Clymans · D. J. Conley

Department of Geology, Lund University, Sölvegaten 12, 22362 Lund, Sweden

e-mail: patrick.frings@geol.lu.se

E. Jeppesen - T. L. Lauridsen

Department of Bioscience, Freshwater Ecology, Vejlsøvej

25, 8600 Silkeborg, Denmark

E. Struyf

Department of Biology, Research Group Ecosystem Management, University of Antwerp, Universiteitsplein 1, 2610 Wilrijk, Belgium lentic systems accumulate $\mathrm{Si}$ via biological conversion of DSi to biogenic silica (BSi). An analysis of new and published data for nearly 700 systems is presented to assess their contribution to the accumulating continental pool. Surface sediment BSi concentrations $(n=692)$ vary between zero and $>60 \% \mathrm{SiO}_{2}$ by weight, apparently independently of lake size, location or water chemistry. Using sediment core BSi accumulation rates $(n=109)$, still no relationships are found with lake or catchment parameters. However, issues associated with single-core accumulation rates should in any case preclude their use in elemental accumulation calculations. Based on lake/reservoir mass-balances $(n=34)$, our best global-scale estimate of combined lake and reservoir Si retention is $1.53 \mathrm{TMol}_{\text {year }}{ }^{-1}$, or $21-27 \%$ of river DSi export. Again, no scalable relationships are apparent, suggesting $\mathrm{Si}$ retention is a complex process that varies from catchment to catchment. The lake Si sink has implications for estimation of weathering flux generation from river chemistry. The size of the total continental $\mathrm{Si}$ pool is poorly constrained, as is its accumulation rate, but lakes clearly contribute substantially. A corollary to this emerging understanding is that the flux and isotopic composition of DSi delivered to the ocean has likely varied over time, partly mediated by a fluctuating continental pool, including in lakes.

Keywords Silica cycle $\cdot$ Biogenic silica $\cdot$ Lake retention $\cdot$ Silicon isotopes 


\section{Introduction}

The global biogeochemical Si cycle is characterised by two discrete sub-cycles of comparable magnitude on the continents and in the oceans. Rivers are the principal link between these sub-cycles, supplying $\sim 85 \%$ of annual inputs of dissolved silicate (DSi) to the ocean, after its mobilisation from terrestrial soils and bedrock. The long-term Si cycle consists of (1) release of dissolved silicate (DSi) and particulate silicates from regolith at the Earth's surface, (2) cycling and partial transfer of DSi and particulates from land to ocean and (3) permanent burial in ocean sediments (see Struyf et al. 2009a and Tréguer and de la Rocha 2013 for reviews). All stages are driven by biological activity and include various reservoirs that act to buffer or even temporarily reverse the long-term unidirectional flux from land to ocean.

Silicate weathering releases DSi and consumes $\mathrm{CO}_{2}$ at a temperature dependent rate, thereby acting as a negative feedback for atmospheric $\mathrm{CO}_{2}$ (Berner et al. 1983). Weathering is strongly biologically mediated through root exudation of organic acids, subsurface $\mathrm{pCO}_{2}$ enrichment, physical breakage and facilitation of soil water flow (Berner 1992; Berner et al. 2005). A substantial fraction of the mobilised DSi enters the soil-vegetation system, where it contributes to the production of biogenic silica (BSi) structures in continental vegetation that convey structural and ecological benefits (Epstein 1999). Continental vegetation BSi production is estimated at $\sim 84 \times 10^{12} \mathrm{~mol}$ Si year $^{-1}$ (Carey and Fulweiler 2012) which is too large to be supported entirely from newly mobilised DSi. Instead, it derives from recycling of a pool of reactive amorphous $\mathrm{Si}$ (ASi) compounds (including $\mathrm{BSi}$ ) in ecosystem soils. This soil-vegetation Si pool is orders of magnitude larger than annual Si mobilisation and has been termed the ecosystem silica filter (Struyf and Conley 2012). This filter buffers DSi export from catchments such that actual $\mathrm{Si}$ export will equal $\mathrm{Si}$ mobilisation from bedrock only when the filter functions at steady-state.

After cycling through continental ecosystems, approximately $6 \mathrm{TMol} \mathrm{DSi} \mathrm{year}{ }^{-1}(1 \mathrm{TMol}=1 \times$ $10^{12} \mathrm{~mol}$ ) is delivered to the oceans via the fluvial system. Annual ocean BSi production of $\sim 240 \mathrm{TMol}$ year $^{-1}$ (Tréguer and De La Rocha 2013) is therefore similarly supported by recycling of previous production. The diatoms dominate ocean BSi production, corresponding to $\sim 40 \%$ of oceanic primary production (Yool and Tyrrell 2003). After death, the BSi is an efficient exporter of organic $\mathrm{C}$ to the deep ocean. Annually, $\sim 3 \%$ escapes dissolution and is permanently removed from the ocean sub-cycle (Tréguer and De La Rocha 2013).

These two linkages-silicate weathering and $\mathrm{BSi}$ export in the ocean-tightly couple the $\mathrm{Si}$ and $\mathrm{C}$ cycles. DSi release from bedrock and subsequent transport to the ocean are key elements in the Earth System. They are commonly assumed to be equivalent and are typically assessed through measurement of stream DSi concentrations and discharge. Yet such an assessment assumes steady-state conditions in the continental Si cycle. On human ( $<100$ years) timescales, steady-state depends on the constancy of $\mathrm{Si}$ pools in the ecosystem filter, where different ecosystems have different weathering, internal recycling and release rates. An emerging paradigm asserts humans have perturbed the balance between these processes, and ecosystem $\mathrm{Si}$ pools are growing or depleting following land use change, agricultural Si export, eutrophication or climate change (Clymans et al. 2011; Struyf et al. 2010a; Conley et al. 2008; Sommer et al. 2013). We now know the modern Si cycle is highly perturbed, so steady-state should not be assumed in the Anthropocene.

On longer timescales, the $\mathrm{Si}$ cycle would be in steady-state if permanent burial in the oceans equals the sum of Si mobilised by weathering and erosion on the continents. On these timescales, and distinct from anthropogenic activity, we hypothesise the continental $\mathrm{Si}$ cycle is not at steady-state and instead is characterised by gradual aggradation or depletion of the ASi pool held in continental soils, sediments and deposits, in response to changing environmental forcings. This has implications for the ultimate flux of DSi from land to ocean and the strength of the silicate weathering$\mathrm{pCO}_{2}$ feedback.

In this contribution, we summarise evidence for non-steady state functioning of the global Si cycle independent of human activity ("An accumulating continental Si pool”). Meybeck and Vörösmarty (2005) conceptualise the fluvial system from soils to estuaries as a series of filters that 'recycle, store, remobilise and transform' material. Within this framework, we focus on a key element-lentic systemsand present a meta-analysis of a compilation of lake/ reservoir sediment $\mathrm{BSi}$ and associated catchment data 
for nearly 700 systems to better understand where and why $\mathrm{Si}$ is being sequestered ("Lake and reservoir $\mathrm{Si}$ accumulation: a meta-analysis"). Our synthesis and interpretation of this dataset highlights uncertainties and flaws in current approaches and the assumption of steady-state. We place our data in the context of our understanding of past and present $\mathrm{Si}$ cycling and demonstrate that river DSi fluxes are variable in magnitude, isotopic composition and spatial distribution over a range of timescales ("Lake $\mathrm{Si}$ accumulation: uncertainties and implications for the global $\mathrm{Si}$ cycle”). Implications of a non-steady-state continental Si pool are highlighted and recommendations formulated for future research priorities.

Throughout, we discriminate between particulate silicates and amorphous Si (ASi). Here, particulate silicate refers to minerals formed in situ during weathering or to unaltered erosional products. ASi also refers to solid phases of $\mathrm{Si}$, but those neoformed from a DSi precursor after movement from its point of mobilisation, i.e. not as an integral step in the weathering process. ASi includes BSi but also various inorganic phases that span a range of crystallinity. For the sake of consistency with previous literature, we retain the term ASi to refer to all neo-formed phases, although we note some clay minerals fulfil our criteria of forming from a translocated DSi precursor, but have a high degree of crystallinity.

\section{An accumulating continental Si pool}

A non-steady state global sediment budget

Many lines of evidence imply current net continental accumulation of both particulate and amorphous $\mathrm{Si}$. The accumulation of particulate silicates is not contentious and is a direct consequence of a timelagged global sediment response to changing climates since the last glacial maximum (Hinderer 2012). Areas of net deposition have long been acknowledged within the context of the carbon cycle (Stallard 1998). The current era of marine transgression, as a recovery from the LGM sea-level lowstand, means many river catchments are actively aggrading in paraglacial areas. For example, in the coterminous United States, $\sim 90 \%$ of eroded material does not reach river mouths (Meade 1988). Floodplains are known to accumulate substantial percentages of river sediment, especially in tectonically active areas (Allison et al. 1998). In particular, large river floodplains appear to buffer sediment delivery on timescales greater than Quaternary environmental changes (Métivier and Gaudemer 1999; Blöthe and Korup 2013). Similarly, colluvial and aeolian sediments are accumulating in many regions, particularly those with agriculturally disturbed sediment budgets (Trimble 1983). Reservoirs annually accumulate about $20 \%$ of the global river sediment flux delivered to the ocean by rivers (Syvitski et al. 2005) and the number of established reservoirs are increasing markedly (Lehner et al. 2011). Lakes and ponds presumably have a similar function (Hay 1998; Houser et al. 2010). Such accumulation is not a realistic long-term situation. The timescales of equilibration are unclear but occur over many millennia. This development of particulate Si pools has implications for the silicate-weathering feedback, since it implies a long-term trend towards a more transport-limited system at a global scale. Longterm sediment disequilibrium is discussed elsewhere (Vance et al. 2009; Goudie and Viles 2012), which also touch upon implications for weathering rates (e.g. Mills et al. 2011). A discussion of silicate-weathering feedback mechanisms is beyond the scope of this manuscript.

\section{Evidence for continental retention of DSi}

In addition, a fraction of the DSi released during weathering also accumulates in lake, reservoir and floodplain sediments or terrestrial soils via the formation and sequestration of ASi. This is well known (Conley et al. 1993a), but a common assumption is that prior to human perturbations accumulation was balanced by losses, such that no net change occurred. The emerging understanding is that these ASi pools are dynamic and respond to environmental forcings, and the timescales of build-up or decay are so long that dynamic equilibrium cannot be assumed. Evidence suggests the modern-day ASi pool is actively expanding, i.e. continental processes currently act as a sink in the $\mathrm{Si}$ cycle, as in the C cycle (Stallard 1998). If correct, this has implications for our understanding of the coupled $\mathrm{Si}$ and $\mathrm{C}$ cycles. It suggests that (a) in some cases observed fluxes of $\mathrm{Si}$ and other elements in streams partially reflect imbalances in the terrestrial biosphere rather than mineral weathering rates, so weathering rates may be systematically under- or 
overestimated, (b) the presence of feedbacks relating terrestrial ASi pool development and weathering rates (Struyf et al. 2010a), and (c) changes in sequestration rates will alter downstream ecology and biogeochemistry via changing elemental stoichiometries.

\section{Evidence for continental DSi retention from global Si-cycle models}

Modelling efforts give a first indication of the importance of this sink. A global Si cycle box-model based on mass-balance principles (Laruelle et al. 2009) suggests 6.4 TMol of DSi mobilised during weathering accumulates annually on the continents as BSi in soils and lake sediments. Similarly, a discrepancy of 12-40 TMol between modelled DSi mobilisation (19-46 TMol year $^{-1}$; Hilley and Porder 2008) and actual fluxes of DSi to the ocean (5.7-7.1 TMol year $^{-1}$; Beusen et al. 2009) suggests the presence of a large, actively accumulating continental ASi pool every year. These two modelling efforts agree on the presence of a large and accumulating reservoir of continental $\mathrm{Si}$, but differ by an order of magnitude, emphasising the need to better constrain the accumulation.

\section{Evidence for continental DSi retention from river geochemistry}

River geochemistry provides further insight. The silicon isotopic ratio $\left(\delta^{30} \mathrm{Si}\right)$ of $\mathrm{DSi}$ in rivers is systematically heavier than the ratio in catchment bedrock, since the lighter ${ }^{28} \mathrm{Si}$ isotope is preferentially incorporated into secondary minerals and BSi (Ziegler et al. 2005), requiring a continental sink to balance river export (Basile-Doelsch et al. 2005). $\delta^{30} \mathrm{Si}$ of DSi typically (but not always) increases along river longitudinal profiles, implying progressive preferential retention of ${ }^{28} \mathrm{Si}$ (Hughes et al. 2012; Fontorbe et al. 2013; Cardinal et al. 2010; Cockerton et al. 2013). Based on mass-balance De La Rocha et al. (2000) concluded that $64 \%$ of weathered silicon is retained in secondary clay minerals, which is in rough agreement with the stoichiometry of weathering reactions. Hughes et al. (2013) find that between 25 and $100 \%$ of $\mathrm{Si}$ is retained by clay formation in subbasins of the Amazon based on the ratios of $\mathrm{Si}$ and cations in bedrock and surface waters. A similar conclusion was reached in the basaltic terrain of Iceland (Georg et al. 2007).

Changes are also observed in $\mathrm{Ge} / \mathrm{Si}$ ratios in global discharge. Ge has similar geochemical behaviour to $\mathrm{Si}$, but is preferentially partitioned into secondary minerals during weathering and clay neoformation (Kurtz et al. 2002). Low Ge/Si ratios reflect incongruent weathering or preferential removal of $\mathrm{Ge}$ from soil solutions or river water. $\mathrm{Ge} / \mathrm{Si}$ ratios in global

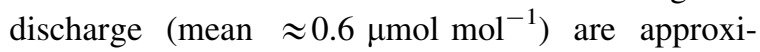
mately half that expected from congruent dissolution of bedrock (Mortlock and Froelich 1987, Kump et al. 2000), implying formation of a Ge-enriched phase, although at what stage between bedrock weathering and river mouth export is unclear. In the Amazon River from Manaus to its mouth, and the Congo River from Kinshasa to its mouth, $\mathrm{Ge} / \mathrm{Si}$ ratios decrease from 1.15 to 0.52 and 0.68 to $0.52 \mu \mathrm{mol} \mathrm{mol}{ }^{-1}$, respectively (Mortlock and Froelich 1987), interpretable as selective removal of Ge into neoformed ASi minerals in lakes, wetlands and floodplains.

Together, river $\delta^{30} \mathrm{Si}$ and Ge/Si imply neoformation of isotopically light and perhaps Ge enriched $\mathrm{ASi}$ phases within the fluvial filter. The fate of these neoformed phases is not well understood.

We cannot completely discount that human impacts are responsible for these results, but believe that they reflect a true long-term disequilibrium in the Si cycle. We note that for the modelling studies, human activity would probably act in the opposite direction, i.e. to increase DSi export on the short-term (Clymans et al. 2011; Conley et al. 2008; Struyf et al. 2010a) though reservoirs and eutrophied systems may provide counter-examples. Moreover, the river geochemistry data tend to derive from regions of the world with limited human impacts. The terrestrial $\mathrm{Si}$ isotope budget could be considered in steady-state if river sediment loads counter-balance the dissolved phase transport. The available data urgently need extending, but suggest this is not the case (Ding et al. 2004, 2011).

\section{Evidence for continental DSi retention from ecosystem-scale studies}

This conclusion of current terrestrial ASi accumulation is validated by ecosystem scale Si studies. They indicate $\mathrm{ASi}$ accumulates as preserved $\mathrm{BSi}$ and inorganic neo-formed ASi phases in the sediments of lakes, wetlands and floodplains and in terrestrial soils 
(Conley 2002). The sizes, location and net aggradation rates of these $\mathrm{Si}$ pools are poorly constrained and current knowledge is limited (Struyf and Conley 2012).

A large soil ASi pool and its impact on DSi release has been observed across a range of landscapes (e.g. Alexandre et al. 1997; Melzer et al. 2012; Gerard et al. 2008; Blecker et al. 2006). Depth distributions of BSi suggest the presence of a refractory pool of ASi which may include aged BSi (Saccone et al. 2006; Cornelis et al. 2011). Soil ASi losses can be via physical erosion or through DSi export after dissolution. Contemporary net accretion or depletion of soil ASi is unclear. In some settings, soils appear to be in equilibrium with their environment (Hewawasam et al. 2013), so presumably there is no net accumulation of ASi. In others, soils can develop or degrade, sometimes disappearing altogether ('regolith stripping;' Phillips 2005) and at other times involving biological activity and weathering profiles to $100 \mathrm{~m}$ depth (Stone and Comerford 1994). Phillips (2010) sees the concept of steady-state soil thickness (and presumably composition) as 'a convenient fiction,' i.e. not true, but occasionally useful. In summary, soils store a huge ASi stock that often will be actively accumulating or depleting and is particularly susceptible to human perturbation (Clymans et al. 2011).

Floodplains are important sinks of particulate $\mathrm{Si}$ (Meybeck and Vörösmarty 2005) and can similarly remove DSi from solution, biologically or though mineral neoformation (Humphries et al. 2010, 2011). However, floodplains can also release DSi through chemical weathering (Lupker et al. 2012), so the net effect is unclear. In wetlands, ASi depth-profiles in boreal (Struyf et al. 2010b), temperate (Struyf et al. 2009b), tropical (Frings et al. in prep.) and freshwater tidal settings (Struyf et al. 2007) show rapid recycling in the uppermost centimetres and minor but nonnegligible long-term accumulation. The net effect of wetlands and floodplains on $\mathrm{Si}$ fluxes is therefore unclear, and a thorough assessment is currently missing due to lack of available data.

In lacustrine sediments, BSi is near-ubiquitous and often accumulates continuously, as demonstrated by its regular use in palaeolimnological investigations. Despite continuous accumulation, we consider lake $\mathrm{Si}$ retention to represent a long-term imbalance in the $\mathrm{Si}$ cycle because it breaks the land-ocean linkage, and a given lake typically only has a finite lifetime (Hinderer and Einsele 2001). The soil ASi pool is probably the most responsive to environmental change in that it can act as both source or sink, while lake sediments typically vary just in the magnitude of the sink. However, we choose to highlight the contribution of lakes to the development of a continental $\mathrm{Si}$ pool because they accumulate consistently and continuously, and a large amount of data is available, while poor data availability and lack of knowledge about the degree of equilibrium preclude quantification of soil ASi stocks. Additionally, lentic systems probably attain equilibrium with their environment much quicker than soils. Further, if we can identify controls on $\mathrm{Si}$ retention for lakes, they may be generalizable to the rest of the continental Si pool.

\section{Lake and reservoir $\mathrm{Si}$ accumulation: a meta- analysis}

Lakes, ponds and reservoirs act as efficient biogeochemical reactors (Benoy et al. 2007; Dean 1999), providing the low turbidity environments needed for efficient assimilation of dissolved nutrients (i.e. Si and other macro- and micro-nutrients) into biomass by primary producers. In lakes and reservoirs, DSi is taken up by siliceous organisms and precipitated as biogenic silica (BSi) in skeletal structures. After the organism dies, this BSi will sink to the sediment where part can become permanently retained (Fig. 1). Lakescale Si mass-balances suggest the Si sink can be a substantial fraction of inflowing Si (Hofmann et al. 2002; Muvundja et al. 2009), so a global scale study of the magnitude and location of the lake Si sink will help to diagnose shifts in the build-up or depletion of $\mathrm{Si}$ in the continental reservoirs.

Harrison et al. (2012) used a spatially explicit global model 'Silica Retention in Reservoirs and Lakes' (SiRReLa) to calculate retention efficiency (\% of inflowing Si retained) as a function of lake trophic state (classified from the NEWS-DIP-HD phosphorus loading model; Harrison et al. 2010) and the ratio of water input to unit lake area, a surrogate for residence time (from Fekete et al. 2002 and Lehner and Doll 2004, respectively). Combined with an estimate of DSi input from the NEWS-DSi model (Beusen et al. 2009), SiRReLa produces an estimate of absolute retention rates (mean $21.7 \mathrm{~g} \mathrm{~m}^{-2}$ year $^{-1}$ ) of $\mathrm{Si}$ in lentic systems. SiRReLa is calibrated on 27 published mass-balances for lakes and reservoirs. 
Fig. 1 Conceptualisation of the mechanism of dissolved $\mathrm{Si}$ (DSi) retention within lake sediments as biogenic $\mathrm{Si}(\mathrm{BSi})$. See text for details

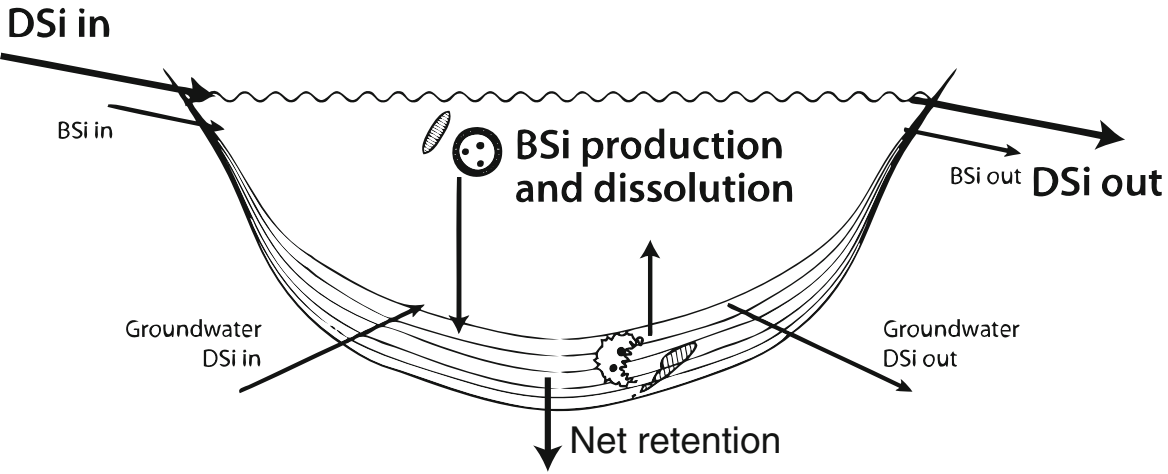

Despite the success of SiRReLa, differences between the retention of $\mathrm{Si}$ in reservoirs and lakes remains unexplored, although studies have shown proportionally larger storage of carbon in reservoirs than in lakes (Tranvik et al. 2009). It also neglects the potential of a wealth of unexplored BSi accumulation rates $\left(\mathrm{AR}_{\mathrm{BSi}}\right)$ or surface sediment $\mathrm{BSi}$ concentrations $\left(\mathrm{C}_{\mathrm{BSi}}\right)$, routinely analysed during (palaeo)limnological investigations as an proxy for lake productivity. Likewise, potential links between catchment processes or characteristics and lake Si sequestration have been neglected. SiRReLa is sensitive to input DSi from the NEWS-DSi model, which is calibrated on river-mouth DSi export, implicitly already accounting for DSi retention. Finally, lakes and reservoirs are treated as one in the calibration and implementation steps despite hydrological and ecological differences. We attempt to address these problems via a synthesis of published and new mass-balance, $\mathrm{AR}_{\mathrm{BSi}}$ and $\mathrm{C}_{\mathrm{BSi}}$ data combined with catchment information. We show $\mathrm{Si}$ accumulation in lakes is a complex process not easily predicted from theoretical first-order controls, but indications are that lentic Si sequestration is a key component in the continental Si sink and can help to reveal imbalances therein.

\section{Approach}

Individual publications were found with searches in ISI Web of Science and relevant data extracted from tables, text or figures. Three classes of data are recognised: Si mass-balances, BSi accumulation rates and surface sediment BSi concentrations. Si massbalances provide whole-lake average $\mathrm{Si}$ accumulation rates, calculated from differences between in- and outflowing $\mathrm{Si}$, whereas $\mathrm{BSi}$ accumulation rates
$\left(\mathrm{AR}_{\mathrm{BSi}}\right)$ represent only one point, usually the deepest, in a lake basin. Finally, surface sediment BSi concentrations $\left(\mathrm{C}_{\mathrm{BSi}}\right.$; \%dry weight) provide no direct information about accumulation rates but may provide proxy information on lake or catchment processes. Supplementary data on lake/reservoir size, location, climate (mean annual temperature and precipitation, MAT and MAP) and physicochemical characteristics were taken from the original text, where mentioned, or otherwise from secondary sources (see below).

This literature data is supplemented with new analyses on sediments from lake surveys in Greenland, Iceland, Denmark, the Azores, Greece, and Tasmania ( $n=182$; Jeppesen et al. 2003a, b and Jeppesen, unpublished data). BSi concentrations were determined from 1 to 5 integrated core-top $(1-3 \mathrm{~cm})$ samples per lake using a standard wet-alkaline extraction (Conley and Schelske 2001) and the molybdate-blue colourimetric reaction (Strickland and Parsons 1968).

Data on lake/reservoir climate, catchment lithology, land cover/vegetation and soil characteristics were extracted from geospatial datasets. Climate variables come from spatially explicit GIS products (monthly precipitation and mean, minimum, and maximum monthly temperature, with 19 extra biologically relevant parameters - the 'BIOCLIM' variables-for the period 1950-2000 at a resolution of 30 arc seconds (Hijmans et al. 2005). Catchment lithology ( 15 classes) comes from a global lithological map, aggregated at $0.5^{\circ} \times 0.5^{\circ}$ resolution (Dürr et al. 2005). Catchment vegetation (22 classes) was derived from the Global Land Cover product (glc2000; Bartholomé and Belward 2005). Catchment heterogeneity is not well captured with this approach, owing to the inability to accurately delineate watersheds and the low resolution of the geospatial data relative to catchment size, so all catchments are therefore 


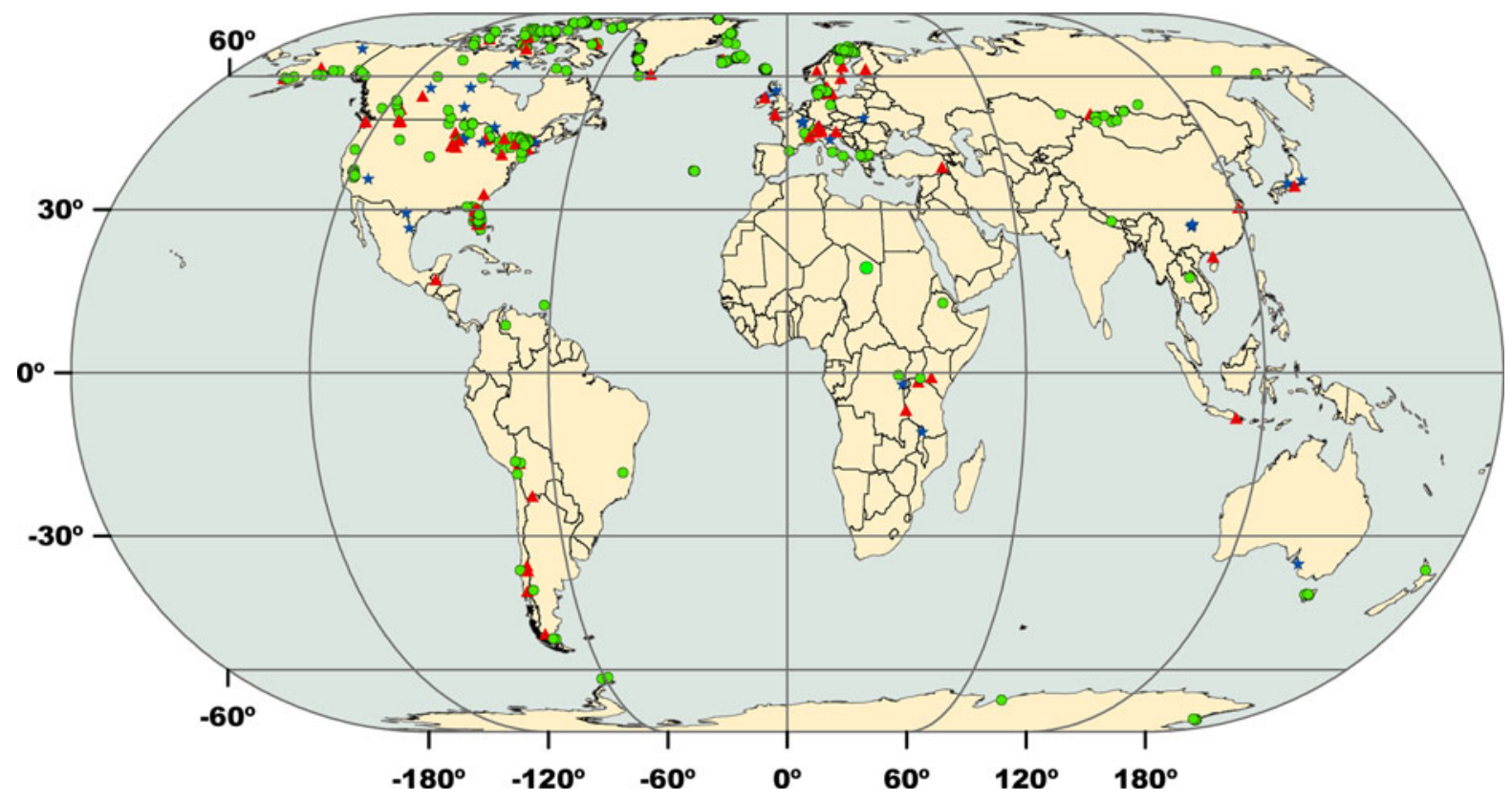

Fig. 2 Location of lakes and reservoirs included in our database. Green points represent surface sediment BSi concentrations, red triangles BSi accumulation rates and blue stars whole-system Si mass-balances. (Color figure online)

represented by a single point. Where the geospatial data identified the point as a water body, the nearest non-water area was selected. If elevation is not in the original publication, it is derived from a global digital elevation model (ASTER or GTOPO30 depending on coverage). All BSi concentration and accumulation rate data refers to $\mathrm{SiO}_{2}$ throughout.

We conceptualise Si retention in lakes/reservoirs as a function of three factors: DSi input, transformation of DSi to BSi, and preservation of BSi. We specifically focus our attention on identifying relationships with catchment lithology/soils, vegetation and climate (firstorder controls on DSi input; Beusen et al. 2009), latitude, nutrients and climate (first order controls on BSi production; Lewis 2011) and $\mathrm{pH}$, lake size/depth and water chemistry (first order controls on BSi preservation; Loucaides et al. 2012). Since catchment vegetation is influenced by the same factors, we investigate whether vegetation type may be used as a proxy for Si retention.

\section{Results}

The dataset consists of 692 lakes and reservoirs, including 749 individual $\mathrm{C}_{\mathrm{BSi}}$ measurements, 118 $\mathrm{AR}_{\mathrm{BSi}}$ determinations and $34 \mathrm{Si}$ mass-balances taken from over 200 (palaeo)limnological publications and
182 new data points. Data cover 47 countries on all seven continents (Fig. 2). A summary is given in Table 1. The dataset incorporates four large training sets of multiple lakes developed for (a) the use of BSi as a palaeoclimatic index $(n=63$; Fortin and Gajewski 2009), (b) the use of Fourier-Transform infrared spectroscopy (FT-IRS) for measuring sediment BSi concentrations ( $n=94$; Rosen et al. 2010), (c) assessment of the contribution of sponge spicule BSi to total sediment BSi in Florida lakes $(n=82$; Conley and Schelske 1993), and (d) assessment of lake sensitivity to acidification ( $n=67$; Conley, unpublished data).

\section{Si mass-balance studies}

Thirty of the thirty-four systems have positive retention rates, i.e. they are net sinks for Si. The remaining systems have negative retention rates, implying they are net sources of DSi to the fluvial system. Based on the documented in- and outflowing Si fluxes for the remaining systems, lakes and reservoirs retain between -163 and $99 \%$ of inflowing DSi, equivalent to sedimentation rates of $-7.3-268 \mathrm{~g} \mathrm{~m}^{-2}$ year $^{-1}$. The systems are detailed in Table 2.

Mean retention efficiency is $37.1 \%$ and the mean accumulation rate is $33.1 \mathrm{~g} \mathrm{~m}^{-2}$ year $^{-1}$. When lakes 
Table 1 Summary of compiled dataset

\begin{tabular}{|c|c|c|c|c|c|c|}
\hline Continent & BSi (\%dw) & $\operatorname{SAR}_{\mathrm{BSi}}\left(\mathrm{g} \mathrm{m}^{-2}\right.$ year $\left.^{-1}\right)$ & Max depth (m) & Area $\left(\mathrm{km}^{2}\right)$ & $\mathrm{pH}$ & $\overline{\mathrm{DSi}}\left(\mathrm{mg} \mathrm{l}^{-1}\right)$ \\
\hline Africa & $8.21 \pm 4.4(7)$ & $38.9 \pm 21.5$ & 363.8 & 24,239 & 9.7 & \\
\hline Antarctica & $1.79 \pm 1.8(8)$ & - & 26.6 & 2 & - & $1.22(1)$ \\
\hline Asia & $8.37 \pm 6.8(15)$ & $155 \pm 211(6)$ & 207.3 & 650 & 8.7 & \\
\hline Europe & $16.59 \pm 13.1(211)$ & $101+159(24)$ & 17.1 & 33 & 6.7 & $0.90(97)$ \\
\hline North America & $9.96 \pm 10.3(403)$ & $84.2 \pm 101(63)$ & 17.9 & 689 & 6.8 & $1.30(120)$ \\
\hline Oceania & $7.26 \pm 2.8(5)$ & - & 13.7 & 286 & - & \\
\hline South America & $13.11 \pm 11.7(15)$ & $205 \pm 278(6)$ & 62.5 & 643 & 7.4 & $7.63(2)$ \\
\hline Global Average & $11.96 \pm 11.59(664)$ & $97.7 \pm 138(103)$ & 29.5 & 884 & 6.78 & $1.18(220)$ \\
\hline
\end{tabular}

Where given, \pm values correspond to 1 standard deviation of the mean, and values in brackets correspond to the number of data points available in that class

with controlled discharge (see Table 2) are grouped with reservoirs, lakes and reservoirs have significantly different relative retention efficiencies (respective means for lakes and reservoirs 64.2 and $13.0 \%$ ) and absolute sedimentation rates (respective means 18.6 and $46.0 \mathrm{~g} \mathrm{~m}^{-2}$ year $^{-1}$ ). Relative retention (\%) is related to residence time and is weakly correlated with the ratio of lake to catchment area (Fig. 3).

Within this dataset, absolute and relative retention rates do not vary systematically with catchment vegetation or lithology. Classification of lakes by area, depth, latitude or elevation does not improve correlations, and relationships are not substantially altered whether lakes and reservoirs are considered separately or together. Similarly, standard multiple linear regression fails to develop robust predictive models for mass balance-based accumulation rates. These results highlight the complex nature of BSi accumulation. For example, temperature influences lake DSi input and siliceous productivity rates, but also alters dissolution rates, confounding any potential correlation that may provide a scalable parameter. Potential differences among bedrock lithologies or catchment vegetation are not apparent despite being recognised as key controls on DSi release, which may perhaps be attributable to the data resolution. A recent reanalysis of the global Nutrient Export from Watersheds (NEWS) models identified similar catchment-to-catchment variability in $\mathrm{N}$ and $\mathrm{P}$ retention (Tysmans et al. 2013).

\section{BSi accumulation rates}

$\mathrm{BSi}$ accumulation rates in sediment cores span three orders of magnitude from $<0.1 \mathrm{~g} \mathrm{~m}^{-2}$ year $^{-1}$ (e.g. Lake
Sanagak; Stewart et al. 2008) to $>500 \mathrm{~g} \mathrm{~m}^{-2}$ year $^{-1}$ (e.g. Laguna de los Pozuelos or Lake Logung; McGlue et al. 2012; Rodysill et al. 2012), with mean $=97.7$ $\mathrm{g} \mathrm{m}^{2}$ year $^{-1}$. Sedimentation rates derived from cores overlap with mass-balance-based estimates, but are on average $\sim 5 \times$ higher. Core based accumulation rates are unrelated to lake size, depth, location, climate or limnological characteristics (Fig. 4) and show no variation among catchment lithological or vegetation classes (Fig. 5). Since BSi accumulation rates are numerous and globally distributed, they have the potential for calibration of a model relating lake and catchment parameters to $\mathrm{AR}_{\mathrm{BSi}}$ that could subsequently be upscaled to the globe. This approach requires accumulation rates at the surface of one sediment core to be representative of whole system long-term $\mathrm{BSi}$ accumulation. In addition to age-depth model uncertainty, which is beyond the scope of this paper, we identify three confounding issues. We believe these should preclude the use of single-core accumulation rates for calculation of whole lake Si sequestration and suggest that the same is true for other elements.

Firstly, sediment accumulation rates vary within and among lake basins (Hilton 1985; Likens and Davis 1975). This variation, known as sediment focussing, creates heterogeneity that is acknowledged, but rarely accounted for (Hilton 1985; Mackay et al. 2012), and typically studies use one core from the deepest part of the lake. Previous work comparing $\mathrm{P}$ and $\mathrm{Fe}$ retention estimates derived from sediment cores and from mass balances explicitly finds a single core is insufficient to account for spatial variability (Dillon and Evans 1993, 2001). Secondly, pore water DSi profiles typically increase 
Table 2 Summary of mass-balance studies used

\begin{tabular}{|c|c|c|c|c|c|c|c|c|c|c|c|c|}
\hline & Name & $\begin{array}{l}\text { Lat. } \\
\left({ }^{\circ} \mathrm{N}\right)\end{array}$ & $\begin{array}{l}\text { Long. } \\
\left({ }^{\circ} \mathrm{E}\right)\end{array}$ & $\begin{array}{l}\text { Elev. } \\
\text { (masl) }\end{array}$ & Class & $\begin{array}{l}\text { Catchment } \\
\text { area }\left(\mathrm{km}^{2}\right)\end{array}$ & $\begin{array}{l}\text { Lake area } \\
\left(\mathrm{km}^{2}\right)\end{array}$ & $\begin{array}{l}\text { Maximum } \\
\text { depth (m) }\end{array}$ & $\begin{array}{l}\text { Residence } \\
\text { time } \\
\text { (years) }\end{array}$ & $\begin{array}{l}\text { Retention } \\
\text { efficiency } \\
\text { (\% input) }\end{array}$ & $\begin{array}{l}\text { SAR } \\
(\mathrm{g} / \mathrm{m} 2 \\
\left.\text { year }^{-1}\right)\end{array}$ & Reference \\
\hline 1 & Suofengying & 27.0 & 106.4 & 837 & Artificial & 21,862 & 5.7 & 837 & 0.02 & -7.3 & -163.7 & 1 \\
\hline 2 & Dongfeng & 26.9 & 106.2 & 700 & Artificial & 1,816 & 19.7 & 970 & 0.10 & -5.3 & -30.5 & 1 \\
\hline 3 & Amistad & 29.5 & -101.1 & 340 & Artificial & - & 263 & 66 & 1.60 & -66.7 & -27.8 & 2 \\
\hline 4 & Seine & 48.3 & 4.3 & 135 & Artificial & 100 & 23 & 17.5 & 0.62 & -14.5 & -9.7 & 3 \\
\hline 5 & Spring & 63.7 & -90.7 & 3 & Lake & 0.306 & 0.0693 & 7.1 & 1.63 & 57.3 & 0.5 & 4 \\
\hline 6 & $\mathrm{P} \& \mathrm{~N}$ & 63.7 & -90.7 & 16 & Lake & 0.286 & 0.0709 & 10.2 & 2.90 & 73.5 & 0.6 & 4 \\
\hline 7 & Far & 63.7 & -90.7 & 31 & Lake & 0.279 & 0.0363 & 5.2 & 2.93 & 79.7 & 0.7 & 4 \\
\hline 8 & Jade & 63.7 & -90.7 & 18 & Lake & 0.166 & 0.037 & 8.9 & 0.85 & 90.2 & 1.9 & 4 \\
\hline 9 & Michigan & 44.0 & -86.9 & 177 & Lake & 117,845 & 58,016 & 281 & 36.00 & 82.2 & 3.0 & 5 \\
\hline 10 & Winnipeg & 52.0 & -97.0 & 217 & Lake & 953,250 & 17,520 & 19 & 2.50 & 49.1 & 3.2 & 6 \\
\hline 11 & Toolik & 68.6 & -149.6 & 760 & Lake & 65 & 1.5 & 25 & 1.00 & 17.1 & 3.5 & 7 \\
\hline 12 & Superior & 47.3 & -85.0 & 182 & Lake & 126,269 & 82383.5 & 406 & 191.00 & 65.2 & 3.5 & 8 \\
\hline 13 & Kivu & -2.0 & 29.0 & 1,460 & Lake & 5,097 & 2,370 & 485 & 100.00 & 54.5 & 5.7 & 9 \\
\hline 14 & Falcon & 26.6 & -99.2 & 92 & Artificial & - & 400 & 34 & 0.80 & 16.7 & 8.2 & 2 \\
\hline 15 & Marne & 48.6 & 4.8 & 135 & Artificial & 100 & 48 & 17.5 & 0.46 & 42.5 & 12.2 & 3 \\
\hline 16 & Mirror & 43.9 & -71.7 & 213 & Lake & 1.03 & 0.15 & 11 & 1.00 & 63.8 & 12.4 & 10 \\
\hline 17 & Aube & 48.3 & 4.4 & 125 & Artificial & 100 & 21 & 17.5 & 0.40 & 48.6 & 12.7 & 3 \\
\hline 18 & Pepin & 44.5 & -92.3 & 207 & Artificial & 122,000 & 103 & 20 & 0.05 & 0.6 & 14.7 & 11 \\
\hline 19 & Southern Indian & 57.0 & -99.0 & 258 & Lake & 242,000 & 625 & 32 & 0.23 & 21.2 & 15.5 & 6 \\
\hline 20 & Solina-Myczkowce & 49.4 & 22.5 & 420 & Artificial & 1,250 & 24 & 60 & 0.58 & 19.7 & 16.0 & 12 \\
\hline 21 & Powell & 56.9 & -111.5 & 1,113 & Artificial & - & 658 & 170 & 3.30 & 8.1 & 16.6 & 2 \\
\hline 22 & Lugano & 47.3 & 9.0 & 270 & Artificial & 270 & 25.1 & 221 & 8.20 & 78.2 & 20.4 & 13 \\
\hline 23 & Mead & 36.3 & -114.4 & 345 & Artificial & - & 640 & 149 & 3.70 & 13.2 & 28.5 & 2 \\
\hline 24 & Neagh & 54.6 & -6.4 & 15 & Lake & 4,500 & 383 & 25 & 1.24 & 59.2 & 32.9 & 14 \\
\hline 25 & Kasumigaura & 36.0 & 140.4 & 0 & Lake & 1,426 & 171.5 & 7.3 & 0.55 & 67.3 & 40.0 & 15 \\
\hline 26 & Malawi & -10.6 & 34.1 & 500 & Lake & 100,500 & 29,600 & 701.5 & 140.00 & 99.1 & 52.2 & 2,16 \\
\hline 27 & Alexandrina & -35.5 & 139.0 & 1 & Artificial & $1,061,469$ & 570 & 4.05 & 0.30 & 39.2 & 53.1 & 17 \\
\hline 28 & Leven & 56.2 & -3.4 & 107 & Lake & 145 & 13.3 & 25.5 & 0.43 & 67.4 & 58.6 & 18 \\
\hline 29 & Biwa & 35.3 & 136.1 & 82.8 & Lake & 3,174 & 672.2 & 103.8 & 5.50 & 79.8 & 63.5 & 19 \\
\hline 30 & Wujiangdu & 27.3 & 106.8 & 700 & Artificial & 27,790 & 47.5 & 760 & 0.14 & 22.8 & 72.8 & 1 \\
\hline 31 & Iron Gate & 44.5 & 12.2 & 708 & Artificial & 3,174 & 104.5 & 53 & 0.03 & 4.1 & 155.0 & 20,21 \\
\hline
\end{tabular}




\begin{tabular}{|c|c|c|c|c|c|c|c|c|c|c|c|c|}
\hline & Name & $\begin{array}{l}\text { Lat. } \\
\left({ }^{\circ} \mathrm{N}\right)\end{array}$ & $\begin{array}{l}\text { Long. } \\
\left({ }^{\circ} \mathrm{E}\right)\end{array}$ & $\begin{array}{l}\text { Elev. } \\
\text { (masl) }\end{array}$ & Class & $\begin{array}{l}\text { Catchment } \\
\text { area }\left(\mathrm{km}^{2}\right)\end{array}$ & $\begin{array}{l}\text { Lake area } \\
\left(\mathrm{km}^{2}\right)\end{array}$ & $\begin{array}{l}\text { Maximum } \\
\text { depth (m) }\end{array}$ & $\begin{array}{l}\text { Residence } \\
\text { time } \\
\text { (years) }\end{array}$ & $\begin{array}{l}\text { Retention } \\
\text { efficiency } \\
\text { (\% input) }\end{array}$ & $\begin{array}{l}\text { SAR } \\
\left(\mathrm{g} / \mathrm{m} 2^{2}\right. \\
\left.\text { year }^{-1}\right)\end{array}$ & Reference \\
\hline 32 & St. Croix & 44.8 & -92.8 & 233 & Artificial & 19,900 & 35.2 & 22 & 0.13 & 10.2 & 174.3 & 11 \\
\hline 33 & Amance & 48.3 & 4.4 & 125 & Artificial & 100 & 0.5 & 15 & 0.03 & 15.8 & 206.4 & 3 \\
\hline 34 & Champaubert & 48.6 & 4.8 & 135 & Artificial & 100 & 0.5 & 15 & 0.11 & 8.9 & 268.8 & 3 \\
\hline
\end{tabular}

Lakes are classed into natural or artificial, where artificial includes both manmade reservoirs and modified natural systems. References are as follows: (1) Wang et al. 2010; (2) Kelly 2001; (3) Garnier et al. 1999; (4) Welch and Legault 1986; (5) Schelske 1985; (6) Hecky et al. 1986; (7) Cornwell and Banahan 1992; (8) Johnson and Eisenreich 1979; (9) Muvundja et al. 2009; (10) Likens et al. 1985; (11) Triplett et al. 2008; (12) Koszelnik and Tomaszek 2008; (13) Hofmann et al. 2002; (14) Dickson 1975; (15) Arai et al. 2012;

(16) Bootsma et al. 2003; (17) Cook et al. 2010; (18) Bailey-Watts et al. 1989; (19) Goto et al. 2007; (20) Teodoru and Wehrli 2005; (21) Friedl et al. 2004
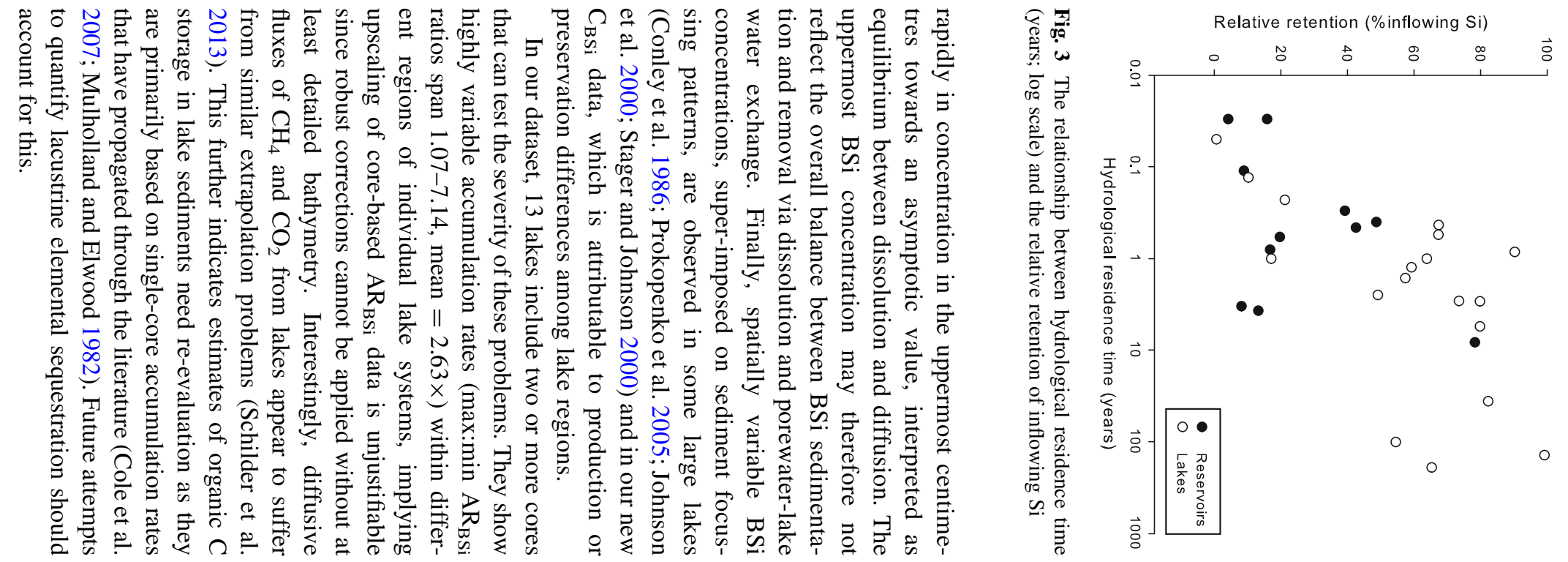

$\mid$



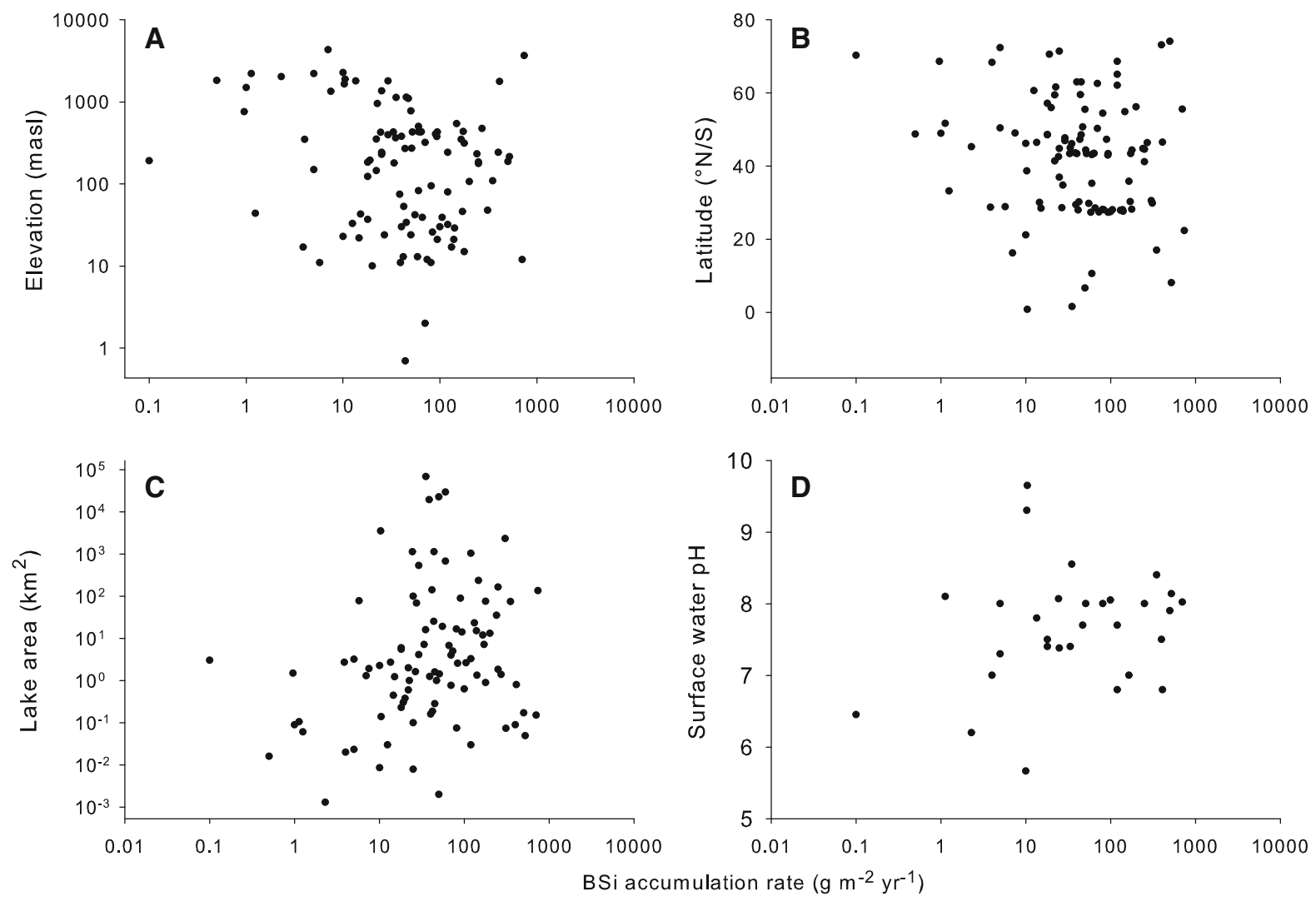

Fig. 4 Lack of significant correlations of variations in sediment BSi accumulation rate $\left(\mathrm{g} \mathrm{m}^{-2} \mathrm{year}^{-1}\right)$ and a Elevation, b Latitude, c Lake surface area $\left(\mathrm{km}^{2}\right)$ and $\mathbf{d}$ Surface water $\mathrm{pH}$. Note the log scales

\section{Si surface sediment concentrations}

Mean surface sediment BSi concentrations are highly variable, ranging from below detection to $61.5 \%$ (lake 58 in Rosen et al. 2010). Lakes have mean $\mathrm{C}_{\mathrm{BSi}}=12.1 \% \mathrm{SiO}_{2}$ by weight and are uncorrelated with surface water chemistry (TP, conductivity, $\mathrm{pH}$ or DSi). At a global scale, the data exhibit no spatial patterns nor any correlation with latitude, altitude or lake size and depth (Fig. 6). They also show no systematic variation among catchment lithological or vegetation classes (data not shown). Exploratory multivariate techniques (also performed on $\mathrm{AR}_{\mathrm{BSi}}$ and the Si budget data) provided no useful insight.

Lakes with BSi concentrations $>50 \%$ tend to be high latitude, low conductivity lakes with diatom species characteristic of low-nutrient, low productivity systems (Rosen et al. 2000). This implies high BSi concentrations do not reflect high productivity but rather lack of dilution and limited dissolution, since diatoms appear to have a competitive advantage in low nutrient environments (Egge and Asknes 1992). By contrast, some other lakes with high BSi concentrations are associated with volcanic activity. Clearly, the mechanisms governing diatomite formation are poorly understood (Wallace 2003), and further research is needed to understand the occurrence of lakes with exceptionally high BSi concentrations. Conversely, high $\mathrm{AR}_{\mathrm{BSi}}$, low $\mathrm{C}_{\mathrm{BSi}}$ lakes-for instance Petén Itzá, Guatemala (Rosenmeier et al. 2004) or Dallund $S \varnothing$, Denmark (Bradshaw et al. 2005b)—suggest high production but dilution by non-siliceous autochthonous production or allochthonous material from the catchments. BSi concentrations are unrelated to core based BSi sedimentation rates $\left(\mathrm{r}^{2}=0.03, n=103\right)$ and to mass-balance-derived estimates $\left(\mathrm{r}^{2}=0.17\right.$, $n=8)$. Further, $\mathrm{C}_{\mathrm{BSi}}$ is variable within lake basins ("BSi accumulation rates"). A bias in the (palaeo)limnological literature towards eutrophic systems further complicates $\mathrm{C}_{\mathrm{BSi}}$ and $\mathrm{AR}_{\mathrm{BSi}}$ use. It is thus 


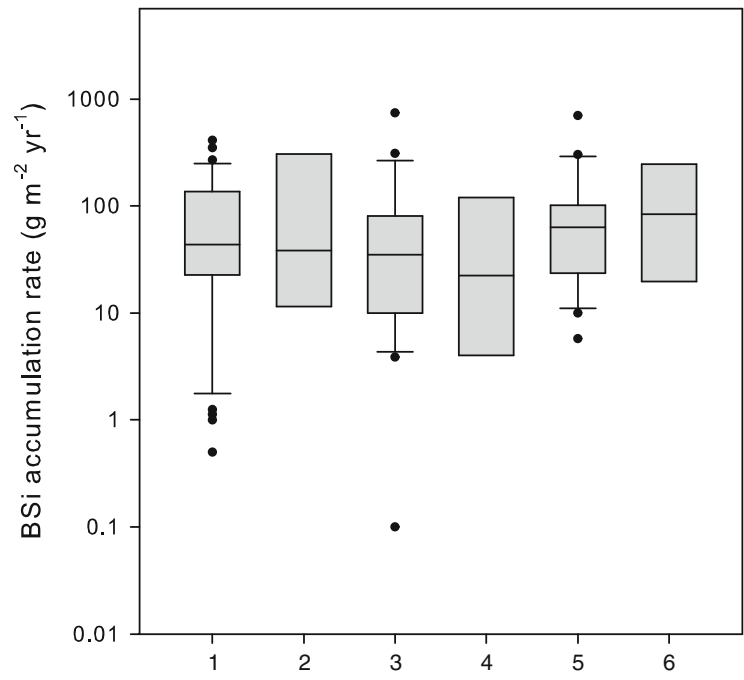

Fig. 5 Variation in $\mathrm{BSi}$ accumulation rate for lakes in catchments with different vegetation classes. Classes are merged from the 22 defined within the GLC GIS product (Bartholomé and Belward 2005) as follows: 1: Tree cover (both broadleaved and needle-leaved), 2: Mosaiced landscape, 3: Shrub/herbaceous cover, 4: Regularly flooded areas, 5: Cultivated and managed cover, 6: Snow, ice or artificial areas

highly unlikely such a compilation of BSi concentrations can contribute to global accumulation estimates.

\section{Lake Si accumulation: uncertainties and implications for the global Si cycle}

An estimate of the lentic Si sink

A primary purpose of this study is to estimate global scale lake $\mathrm{Si}$ storage and to indicate where major uncertainties remain. The only attempt to date (Harrison et al. 2012) used $27 \mathrm{Si}$ mass balances, including 24 of those compiled here (different inclusion criteria) to calibrate the SiRReLa model, but did not explore the use of $\mathrm{AR}_{\mathrm{BSi}}$ or $\mathrm{C}_{\mathrm{BSi}}$ data or potential links between catchment processes and $\mathrm{Si}$ accumulation. Our analysis demonstrates that core-based accumulation rates are unsuitable for upscaling ("BSi accumulation rates"), that surface sediment BSi concentrations are unrelated to accumulation rates ("Si surface sediment concentrations") and that inclusion of catchment parameters does not help create scalable models, so only 30 mass-balance based sedimentation rates (" $\mathrm{Si}$ mass-balance studies") remain. Therefore we have developed a single, global scale estimate for lentic $\mathrm{Si}$ retention. We account for the differences in lake and reservoir Si storage ("Si mass-balance studies") with two different calculated accumulation rates (lakes = $18.2 \mathrm{~g} \mathrm{~m}^{-2}$ year $^{-1}$; reservoirs $=46.0 \mathrm{~g} \mathrm{~m}^{-2}$ year $^{-1}$, "Si mass-balance studies", Table 3). We take a global lake area of $4.2 \times 10^{6} \mathrm{~km}^{2}$, of which $43 \%$ is systems less than $1 \mathrm{~km}^{2}$ (Downing et al. 2006) and the Global Reservoir and Dam (GRanD) database (Lehner et al. 2011) area of reservoirs of $0.3 \times 10^{6} \mathrm{~km}^{2}$.

Using these accumulation rate and area estimates, we calculate a lake Si sink of $1.30 \mathrm{TMol}$ year and a reservoir sink of $0.23 \mathrm{TMol}$ year, for a combined $\mathrm{Si}$ sink of $1.53 \mathrm{TMol}$ year. Previous estimates put lake Si retention at $1.49 \mathrm{TMol} \mathrm{year}^{-1}$ (Harrison et al. 2012) or 2.8 $\mathrm{TMol} \mathrm{year}^{-1}$ (Laruelle et al. 2009). Campy and Meybeck (1995) estimated a mean lake accumulation rate of $20 \mathrm{~g} \mathrm{SiO}_{2} \mathrm{~m}^{-2}$ year $^{-1}$, giving a global retention of $1.4 \mathrm{TMol}$. Land to ocean river DSi transport is between 5.66 and $7.12 \mathrm{TMol}_{\text {year }}{ }^{-1}$ (Beusen et al. 2009; Durr et al. 2011). Our updated estimate of combined lake and reservoir retention (1.53 TMol) confirms that $\mathrm{BSi}$ accumulation is towards the low range of previous estimates, with lakes and reservoirs accumulating an additional 21-27\% of global Si outputs to the ocean. At a global scale, our approach predicts the greatest retention to occur in regions of high lake density, i.e. the northern high latitudes.

Our approach differs from SiRReLa (Harrison et al. 2012) in two key ways. Firstly, our results are not spatially explicit. An advantage is inclusion of DSi input to lakes, a key but uncertain parameter that SiRReLa is sensitive to, is not needed. Further, in SiRReLa it is unclear where small lakes are positioned in the landscape (cf. Meybeck and Vörösmarty 2005), and how they receive their DSi and water, since they are below the scale of the DSi and hydrology inputs. In our analysis we observe no size or elevation dependency in $\mathrm{C}_{\mathrm{BSi}}$ or $\mathrm{AR}_{\mathrm{BSi}}$ (" $\mathrm{BSi}$ accumulation rates" and "Si surface sediment concentrations"), implying that our analysis is insensitive to the position of lakes in the landscape in contrast to SiRReLa. Secondly, we treat lakes and reservoirs separately so different results are obtained despite the estimates deriving from similar datasets. We therefore generate a smaller reservoir Si sink and a larger lake Si sink. 

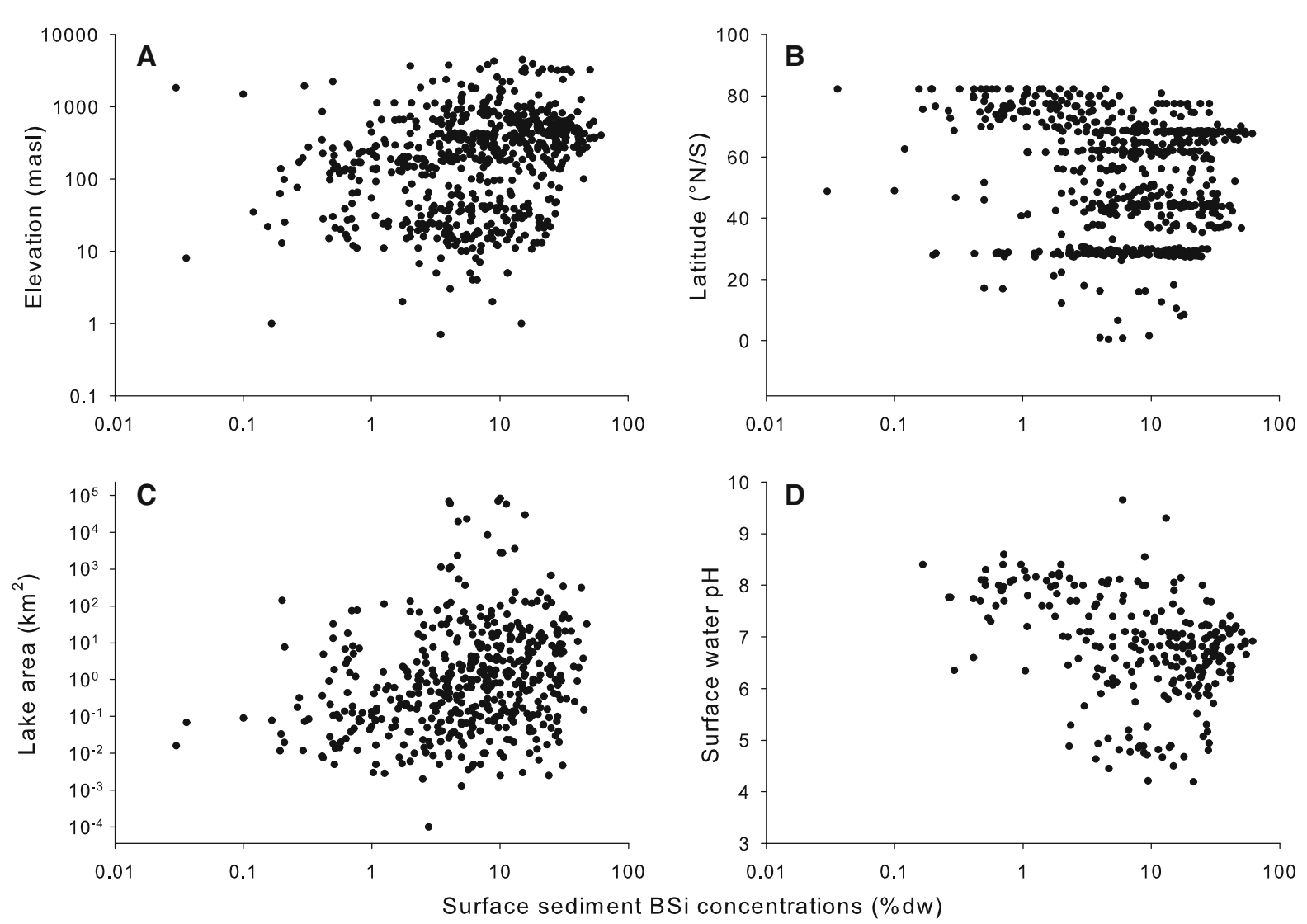

Fig. 6 Lack of significant correlations between reported surface sediment BSi concentrations (\%dw) and a Elevation, b Latitude, c Lake surface area $\left(\mathrm{km}^{2}\right)$ and $\mathbf{d}$ Surface water $\mathrm{pH}$. Note the log scales

Impact of reservoirs on the Si cycle

Our compilation shows that lakes and reservoirs accumulate $\mathrm{Si}$ differently. Reservoirs accumulate faster, but with less efficiency than lakes and with less dependency on residence time (Fig. 3). Beusen et al. (2009) estimate that $18-19 \%$ of DSi in North America may be retained behind dams. In the SiRReLa model, 0.52 TMol Si year ${ }^{-1}$ (7.3-9.1\% of total DSi export) are trapped behind dams. In our global analysis, reservoirs retain 0.23 $\mathrm{TMol} \mathrm{Si} \mathrm{year}^{-1}$ (3.2-4.0\% of total DSi export), confirming that dams act as a significant perturbation in the modern $\mathrm{Si}$ cycle. Average retention efficiency of reservoirs is $24 \%$, implying the local impact of dams can be large, especially when a cascade of dams exists, as on the Danube or the Daugava (Friedl et al. 2004; Humborg et al. 2006; Humborg et al. 2008). Si retention efficiency is related to water residence time, and impoundments with relatively short residence times-

Table 3 Summary of Si retention in lakes and reservoirs

\begin{tabular}{llllll}
\hline & $\begin{array}{l}\text { Global surface } \\
\text { area }\left(10^{6} \mathrm{~km}^{2}\right)^{\mathrm{a}}\end{array}$ & $\begin{array}{l}\text { Relative retention } \\
\text { efficiency }(\%)\end{array}$ & $\begin{array}{l}\text { BSi sedimentation } \\
\text { rate }\left(\mathrm{g} \mathrm{m}^{-2} \text { year }^{-1)}\right.\end{array}$ & $\begin{array}{l}\text { Total retention } \\
(\mathrm{TMol} \mathrm{Si})\end{array}$ & $\begin{array}{l}\% \text { of total river } \\
\mathrm{DSi} \text { export }\end{array}$ \\
\hline Lakes & 4.2 & 64 & 18.2 & 1.30 & $24-30$ \\
Reservoirs & 0.3 & 13 & 46.0 & 0.23 & $3.2-4.0$ \\
\hline
\end{tabular}

\footnotetext{
${ }^{a}$ From Lehner and Doll (2004) and Lehner et al. (2011)
}

b River DSi flux from Beusen et al. (2009) 
"run of the river" dams-therefore will have a smaller impact on dissolved fluxes.

Implications for weathering rate calculation

Chemical weathering of silicates consumes $\mathrm{CO}_{2}$ at a rate that is temperature and $p \mathrm{CO}_{2}$ dependent (Beaulieu et al. 2010; Lenton and Britton 2006), balancing volcanic $\mathrm{CO}_{2}$ input and constituting a long-term thermostat on Earth's climate. The most powerful means for assessing this flux is through chemical mass-balance/stoichiometric analysis of input/output water chemistry from well-characterised watersheds (Bricker et al. 2005; Garrels and Mackenzie Garrels and Mackenzie 1967). This assumes catchment equilibrium; i.e. no net creation or depletion of soil-plant elemental pools, which we know to be invalid for at least Si (Conley et al. 2008; Struyf et al. 2010a), and probably for other bioactive elements (e.g. Chaudhuri et al. 2007). It also assumes that there is no loss within the fluvial system at the scale under consideration. Some of these assumptions may hold for small, headwater catchments, but are untested for large (continental-scale) systems (e.g. Gaillardet et al. 1999). Calculations of weathering rates occasionally use DSi flux as a proxy for denudation rate (White and Blum 1995; Bluth and Kump 1994). Coupled with river transport of non-dissolved, but highly reactive $\mathrm{Si}$ phases (Conley 1997), our results suggest imbalances in the continental $\mathrm{Si}$ pool, including lake Si retention, may cause systematic mis-estimation of weathering fluxes and $\mathrm{CO}_{2}$ consumption rates, particularly when using river $\mathrm{Si}$ fluxes at large spatial scales.

To our knowledge, no systematic assessment of the degree of lentic elemental retention has been undertaken for the vast majority of elements. It is therefore necessary to quantify the size of the lake sink for the base cations, trace elements or isotope systems more commonly used in weathering rate/ $\mathrm{CO}_{2}$ consumption rate calculations. They are often bioactive or can substitute for a bioactive element, so biologically mediated lake retention can feasibly occur (cf. Fig. 1). Evidence suggests that sequestration associated with $\mathrm{BSi}$ alone can be large. We know that vegetation BSi structures can incorporate relatively large amounts of trace elements (Kameník et al. 2013), although whether the same is true for siliceous organisms that actively uptake DSi is unclear. Preliminary work by
Emoto et al. (2013) shows marine diatom BSi has elemental concentrations at levels close to the concentrations of the continental crust, which is much higher than expected. Cell-specific analysis using synchrotron radiation demonstrates that diatoms can accumulate excess quantities of the micronutrient $\mathrm{Fe}$ (Nuester et al. 2012), and this productivity is key in removing $\mathrm{Fe}$ from surface waters of the Southern Ocean (Ingall et al. 2013). Dillon and Evans (2001) and Nürnberg and Dillon (1993) present Fe budgets for a series of Canadian lakes draining the Cambrian shield where $\mathrm{Fe}$ retention seems to be important, hinting at a similar freshwater mechanism. The freshwater diatom Asterionella formosa was shown to incorporate substantial but variable amounts of $\mathrm{K}$, $\mathrm{Mg}$, and Ca during a spring bloom in the eutrophic Rossthere Mere, UK (although less than other nondiatom groups; Krivtsov et al. 2000). Retention of the major base cations $\left(\mathrm{Ca}^{2+}, \mathrm{K}^{+}, \mathrm{Mg}^{2+}, \mathrm{Na}^{+}\right)$from massbalance seems to be minor in some systems (Callender and Granina 1997; Jeffries et al. 1988), and more significant in others (Einsele et al. 2001), and can proceed inorganically in hard-water systems, but this issue has never been addressed systematically. Overall, this represents a major knowledge gap that may cause systematic underestimation of continental-scale weathering rates.

Impact on lakes on magnitude and isotopic signature of land-ocean DSi flux

\section{Importance of lakes for the magnitude of land-ocean DSi flux}

The presence of lakes reduces the flux of DSi and other nutrients to the ocean. The reduction (relative to a landscape with no lakes) is most extreme in regions with high lake density (Conley et al. 2000). Bernard et al. (2010, 2011) demonstrates that the spatial distribution of $\mathrm{Si}$ inputs to the oceans is vital to capture observed variability in ocean models. A landscape with a more (or less) efficient lake sink would deliver less (or more) nutrients ( $\mathrm{Si}$, but also e.g. N, P, Fe) to the coastal zone, and this change would come disproportionately from the northern high latitudes. Not only could total nutrient quantities vary - the stoichiometry, important for determining phytoplankton community compositionwould presumably also shift. The impact on coastal 
zone and open ocean ecology and biogeochemistry needs assessing with spatially explicit models, given the importance of ocean biogeochemistry in modulating and driving global climate change.

\section{Importance of lakes for isotopic signature of land- ocean DSi flux}

The presence of lakes also increases the silicon isotopic signature $\left(\delta^{30} \mathrm{Si}\right)$ of river DSi. By isotope mass-balance:

$\delta_{\text {input }}=\left(\delta_{\text {input }+\varepsilon} \cdot f_{\mathrm{BSi}}\right)+\left(\delta_{\text {riv }} \cdot f_{\text {riv }}\right)$

where $\delta_{\text {input }}$ and $\delta_{\text {riv }}$ are the isotope ratios of the DSi that enter the river system and the oceans, and $f_{B S i}$ and $f_{r i v}$ are the fractions of this DSi that are retained in lake sediments and are delivered to the oceans, respectively. Assuming a similar fractionation $\left(\varepsilon_{\mathrm{BSi}}^{30}\right)$ of freshwater and marine diatoms of $-1.1 \%$ (Alleman et al. 2005; De La Rocha et al. 1997) and using our retention estimate and an ocean DSi delivery of 6.2 $\mathrm{TMol} \mathrm{year}^{-1}$, we find lake/reservoir Si storage increases river $\delta^{30} \mathrm{Si}$ by $\sim 0.30 \%$, independent of the $\delta_{\text {riv }}$ value used. This implies downstream increases in $\delta^{30} \mathrm{Si}$ as $\mathrm{Si}$ is progressively retained, consistent with the limited observations (Cockerton et al. 2013; Fontorbe et al. 2013; Hughes et al. 2012). Confirmation of this effect has been demonstrated in both lake dominated boreal regions (Engstrom et al. 2010) and in the tropical Congo river (Hughes et al. 2012).

If lake $\mathrm{Si}$ retention efficiency varies, then the magnitude, $\delta^{30} \mathrm{Si}$ and spatial distribution of $\mathrm{DSi}$ delivered to the ocean will vary correspondingly. This may necessitate consideration in palaeoceanographic studies using $\delta^{30} \mathrm{Si}$ of sedimentary $\mathrm{BSi}$ to trace productivity or Si cycling (e.g. De La Rocha 2006; De La Rocha et al. 1998, Egan et al. 2013) that commonly assume constant ocean-input $\delta^{30} \mathrm{Si}$. Ocean $\delta^{30} \mathrm{Si}$ can be altered by shifting in the relative contributions of river and hydrothermal $\mathrm{Si}$, as envisaged by De La Rocha and Bickle (2005), but also by a shift in input $\delta^{30} \mathrm{Si}$ itself. Rivers supply $\sim 85 \%$ of ocean DSi (Tréguer and De La Rocha 2013), with the majority of the remainder coming from hydrothermal inputs, so ocean $\delta^{30} \mathrm{Si}$ is relatively insensitive to changing total river DSi fluxes, but relatively sensitive to changing river $\delta^{30} \mathrm{Si}$ (De La Rocha and Bickle 2005; Georg et al. 2009).
Mechanisms to induce variations in lake $\mathrm{Si}$ retention efficiency

\section{0-1,000 Year timescales}

Several centennial to millennial scale ontogenetic mechanisms exist to alter lake Si retention efficiency and thereby the magnitude and $\delta^{30} \mathrm{Si}$ of river DSi fluxes. Time-progressive, regionally coherent trends in lake chemistry are observed over millennial scales following deglaciation (Engstrom et al. 2000; Boyle 2007; Fritz and Anderson 2013). However, broad-scale relationships between lake chemistry and Si accumulation are lacking in our dataset, suggesting that $\mathrm{Si}$ retention changes in response to lake or catchment ontogeny do not vary in a consistent manner. Sediment infilling (Bradshaw et al. 2005a, b) can also impact Si retention since retention efficiency is broadly related to residence time (Fig. 3). A reduction in lake volume may decrease the magnitude of Si retained and lessen its subsequent impact on river $\delta^{30} \mathrm{Si}$. Typical Holocene lake sediment accumulation rates for glacial lakes are in the range 0.5-4 mm year ${ }^{-1}$ (Hodder et al. 2006; Odgaard 1993; Beck et al. 2001), which is sufficient to completely remove small lakes in a few millennia or less (Englund et al. 2013). This implies gradual but progressive reduction of residence time and landscape retention efficiency, assuming similar hydrology, and consequently a reduction in the Si retention efficiency of the northern high latitudes, increasing DSi fluxes and decreasing downstream $\delta^{30} \mathrm{Si}$. However, coeval changes in regional hydrology, lake levels or catchment weathering intensities in response to changing climates may confound this, requiring detailed multicore lake studies combined with modelling efforts for a full appreciation. In particular, tropical to sub-tropical hydroclimatology can change on these timescales, impacting vegetation dynamics and lake functioning in these regions (Burrough et al. 2007).

\section{0,000 Year timescales}

On glacial-interglacial (G-IG) timescales, drastic changes occur in climate, ecology and hydrology. Variation in $\delta^{30} \mathrm{Si}$ of $\mathrm{BSi}$ in ocean sediments spans $\sim 1 \%$ over G-IG cycles, typically interpreted in terms of diatom Si utilisation and assuming constant input (De La Rocha et al. 1998). An emerging understanding is that adjustments in terrestrial $\mathrm{Si}$ 
cycling may alter the supply and isotopic signature of Si to the ocean (Opfergelt et al. 2013; Georg et al. 2006, 2009). Opfergelt et al. (2013) find lower $\delta^{30} \mathrm{Si}$ of DSi in glaciated than non-glaciated streams draining basaltic terrain in Iceland, which is attributed to reduced weathering intensities in non-glaciated areas (cf. Tranter 2005). They extrapolate this to argue river $\delta^{30} \mathrm{Si}$ signals vary over G-IG cycles, changing ocean $\delta^{30} \mathrm{Si}$ and necessitating consideration in palaeo-interpretation of silicon isotopes. Georg et al. (2009) present a related hypothesis whereby shifting contributions of groundwater and river discharge to total ocean $\mathrm{Si}$ input causes a $\sim 0.2 \%$ decrease in net input in glacial periods. Today, lake occurrence peaks in regions between $50^{\circ}$ and $70^{\circ} \mathrm{N}$ (Lehner and Doll 2004) — most being glacial relics (Hutchinson 1957). Both our analysis and that of SiRReLa indicate that the regions of the world with the greatest $\mathrm{Si}$ retention in absolute and relative terms correspond to previously glaciated areas. Therefore, lake $\mathrm{Si}$ retention is a corollary to these hypotheses and can increase further the difference between glacial and interglacial $\mathrm{Si}$ cycling and delivery. The cumulative effect of these three mechanisms, plus altered weathering regimes (Vance et al. 2009), may be changes in river Si delivery large enough to substantially impact wholeocean $\delta^{30} \mathrm{Si}$ on G-IG timescales. The feasibility of this should be a future research priority, particularly given recent suggestions of a much shorter oceanic $\mathrm{Si}$ residence time (Jeandel and Oelkers 2013).

\section{Geological variation in lake Si retention efficiency}

Contemporary $\mathrm{Si}$ retention processes may not be applicable to pre-Quaternary periods of extended nonglaciation-for example, the Miocene (23-5.3 Ma) or even the relatively cooler Pliocene (5.3-2.6 Ma). Given infill processes and the lack of glacial activity to deepen or replace them, landscape lake distributions, especially in the northern high latitudes, would be radically different (Pound et al. 2013). With our emerging understanding of the role of continental waters in the biogeochemical cycling of $\mathrm{Si}$ and $\mathrm{C}$, we urgently need a better picture of how the landscape looked in the past. Crudely assuming the LGM ice sheets extended to $50^{\circ} \mathrm{N} / \mathrm{S}$ and using the lake latitudinal distribution of Downing and Duarte (2009), then $\sim 44 \%$ of today's lake area is found in deglaciated regions. A rough calculation similar to Eq. (1) shows that a $90 \%$ reduction in retention above these latitudes, i.e. matching lake distribution to the rest of the globe, increases DSi fluxes by $0.52 \mathrm{TMol}_{\text {year }}{ }^{-1}$ and lowers $\delta^{30} \mathrm{Si}$ by $\sim 0.1 \%$ relative to modern values. This is within the precision of mass spectrometry but neither sufficient nor rapid enough to alter interpretations of marine $\mathrm{BSi} \delta^{30} \mathrm{Si}$ centred on $\mathrm{Si}$ utilisation shifts.

However, in such a scenario, a warmer, wetter world would presumably be closer to a transport limited weathering regime with a greater weathering intensity. This implies the ratio of DSi released to Si retained in clays and ASi will increase, but the magnitude and even direction of the corresponding change in isotopic signature of river fluxes is unclear. This potentially confounds attempts to use silicon isotopes to address questions of long-term changes in ocean Si cycling (Siever 1991, 1992) or terrestrial weathering regimes. We clearly and urgently need a better framework for understanding and predicting river DSi fluxes and their isotopic composition. Modelling studies that explicitly incorporate a dynamic continental Si pool in lakes and soils will be a helpful first step.

\section{Synthesis and conclusions: variations in the continental $\mathrm{Si}$ pool}

Conceptualisation of the Si cycle has changed drastically in the last two decades. Traditionally, Si was not thought to be biologically impacted and so transport to the ocean simply reflected chemical weathering (Fig. 7a). However, now we know the terrestrial Si cycle is strongly biologically mediated (Conley 2002), which creates and recycles a pool of reactive $\mathrm{Si}$ in soils and sediments. This supports most new BSi production and is probably the source of most of the Si delivered to the fluvial system (Derry et al. 2005; Pokrovsky et al. 2013). Our new understanding of the Si cycle (Fig. 7b) emphasises the role of inland waters and terrestrial ecosystem cycling in determining the total delivery to the oceans.

We have long known there is a large pool of $\mathrm{ASi}$ present on the continents and that it effectively buffers $\mathrm{Si}$ release to the oceans. We also know that human activity perturbs this pool through damming, deforestation, agriculture and more (Ittekkot et al. 2006). Contemporary transient, non-steady state conditions attributable to humans have been identified (e.g. 

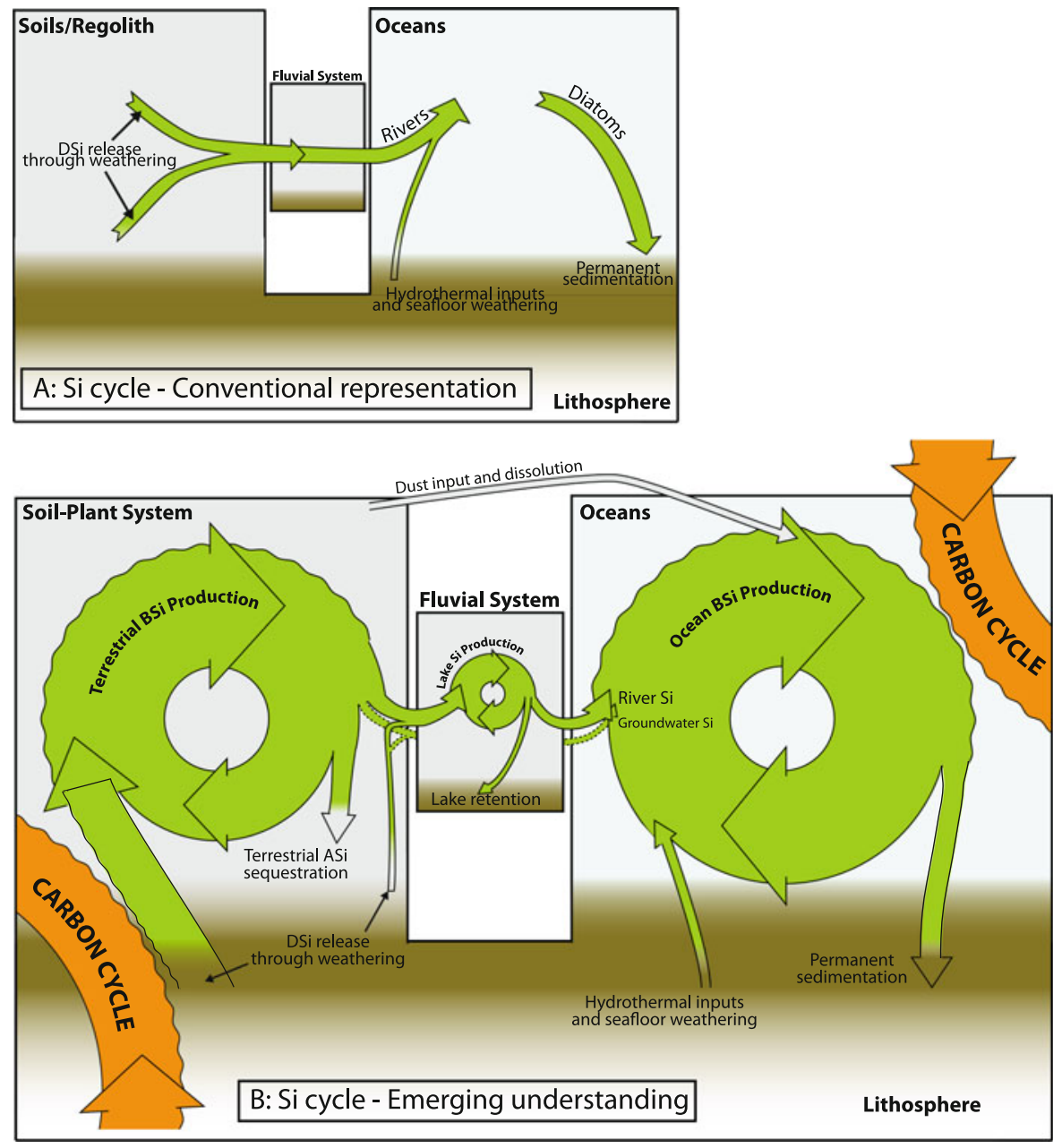

Fig. 7 Our emerging understanding of the Si cycle $(B)$ relative to a conventional conceptualisation $(A)$. This new understanding emphasises a biological control over the majority of Si cycling, b that currently, more $\mathrm{Si}$ is released from weathering than is delivered to the oceans, implying net continental retention, c that the majority of Si likely cycles through the soil-vegetation pool before release and $\mathbf{d}$ the ability of the fluvial system to transform and retain $\mathrm{Si}$ (although not shown here, floodplains,

Sommer et al. 2013; Conley et al. 2008; Clymans et al. 2011). Yet, an implicit assumption remains that there exists a natural steady-state. We are becoming aware that this may be an over-simplification, since we have no adequate estimate of the time that it takes for an ecosystem $\mathrm{Si}$ pool to arrive at equilibrium with its environment. This depends in part on the timescale under consideration. On short timescales $(<100$ years, human activity notwithstanding), the lentic Si sink can probably be considered at equilibrium, but on longer wetlands and estuaries are also recognised as key components in the global Si cycle). Arrow sizes are broadly proportional to flux magnitudes. Two key linkages with the carbon cycle are also shown: $\mathrm{CO}_{2}$ consumption during chemical weathering of silicate minerals, and $\mathrm{BSi}$-associated export of organic carbon to the deep ocean. See the main text and recent reviews (Struyf et al. 2009a; Tréguer and De La Rocha 2013) for more detail

( $>1,000$ years) timescales many (non-tectonic) lakes are just transient features in the landscape. Indeed, on these timescales the ultimate fate of the accumulated (highly reactive, isotopically light) $\mathrm{BSi}$ and other accumulated nutrients in lentic sediments is uncertain. A significant fraction may be transported to the continental margins or sub-glacially weathered during periods of extended glaciation.

The other large continental ASi pools, especially in soils and in floodplains, probably display similar 
time-lagged responses to environmental changes beyond those of human activity. Several knowledge gaps hinder understanding in this regard. The timescales of equilibration are unknown and nor do we know how weathering rates or recycling efficiency vary from ecosystem to ecosystem (including lakes). These should be future research priorities. Lakes themselves are archives of landscape dynamics, making them an ideal place to start. Such considerations are not yet common in paleolimnological studies, although some pioneering studies do explicitly consider the build-up or depletion of a $\mathrm{Si}$ pool (Street-Perrott et al. 2008; Brown 2011).

In this work, we have attempted to investigate the role of the lentic Si sink:

- Lakes and reservoirs annually retain large amounts of river DSi as BSi in their sediments, making them a key sink in the global Si cycle equivalent to an additional $21-27 \%$ of total DSi delivered to the oceans.

- Use of single core accumulation rates is not recommended for derivation of global retention since they do not accurately reflect whole-lake conditions. Multi-core estimates or mass-balance studies are more accurate methods.

- Lake BSi surface concentrations and accumulation rates vary from lake to lake in what appears to be a stochastic manner due to the complex and confounding factors that control DSi input to a system, BSi production and BSi preservation.

- Lakes cause Si exports rates from catchments (and perhaps those of other elements) to be systematically underestimated, implying underestimation of weathering rates as well. This is particularly true at continental scales where the potential for sequestration is higher, but may also be relevant in smaller systems. The same is probably true for floodplains and wetlands, but this remains to be demonstrated.

- Lake BSi retention changes the isotopic signature of river water reaching the oceans. Mechanisms that can alter the lake sink efficiency will subsequently alter the magnitude and isotopic signature of river DSi fluxes. Alone, this process is probably insufficient to impact the isotopic signature by a large amount, but in conjunction with changing weathering regimes it requires consideration in palaeoenvironmental studies and incorporation into biogeochemical models.

Acknowledgments DJC acknowledges financial support from the Wallenberg Foundation and the Swedish National Science Foundation (VR). ES would like to thank FWO and BELSPO for continued funding of research on biological Si cycling.

\section{References}

Alexandre A, Meunier JD, Colin F, Koud JM (1997) Plant impact on the biogeochemical cycle of silicon and related weathering processes. Geochim Cosmochim Acta 61:677-682

Alleman LY, Cardinal D, Cocquyt C, Plisnier PD, Descy JP, Kimirei I, Sinyinza D, Andre L (2005) Silicon isotopic fractionation in Lake Tanganyika and its main tributaries. J Great Lakes Res 31:509-519

Allison M, Kuehl S, Martin T, Hassan A (1998) Importance of flood-plain sedimentation for river sediment budgets and terrigenous input to the oceans: insights from the Brahmaputra-Jamuna River. Geology 26:175-178

Arai H, Fukushima T, Komatsu K (2012) Increase in silicon concentrations and release from suspended solids and bottom sediments in Lake Kasumigaura, Japan. Limnology 13:81-95

Bailey-Watts AE, Smith IR, Kirika A (1989) The dynamics of silica in a shallow, diatom-rich Scottish Loch II: the influence of diatoms on an annual budget. Diatom Res 4:191-205

Bartholomé E, Belward AS (2005) GLC2000: a new approach to global land cover mapping from Earth observation data. Int J Remote Sens 26:1959-1977

Basile-Doelsch I, Meunier JD, Parron C (2005) Another continental pool in the terrestrial silicon cycle. Nature 433:399-402

Beaulieu E, Godderis Y, Labat D, Roelandt C, Oliva P, Guerrero B (2010) Impact of atmospheric CO2 levels on continental silicate weathering. Geochem Geophys Geosyst 11:18

Beck C, Van Rensbergen P, De Batist M, Berthier F, Lallier S, Manalt F (2001) The late Quaternary sedimentary infill of Lake Annecy (northwestern Alps): an overview from two seismic-reflection surveys. J Paleolimnol 25:149-161

Benoy G, Cash K, McCauley E, Wrona F (2007) Carbon dynamics in lakes of the boreal forest under a changing climate. Environ Rev 15:175-189

Bernard CY, Laruelle GG, Slomp CP, Heinze C (2010) Impact of changes in river fluxes of silica on the global marine silicon cycle: a model comparison. Biogeosciences 7:441-453

Bernard CY, Durr HH, Heinze C, Segschneider J, Maier-Reimer E (2011) Contribution of riverine nutrients to the silicon biogeochemistry of the global ocean-a model study. Biogeosciences 8:551-564

Berner RA (1992) Weathering, plants, and the long-term carbon cycle. Geochim Cosmochim Acta 56:3225-3231 
Berner RA, Lasaga AC, Garrels RM (1983) The carbonate-silicate geochemical cycle and its effect on atmospheric carbon dioxide over the past 100 million years. Am J Sci 283:641-683

Berner EK, Berner RA, Moulton KL (2005) Plants and mineral weathering: present and past. In: Drever JI (ed) Surface and ground water, weathering, and soils. Pergamon, Oxford, pp 169-188

Beusen AHW, Bouwman AF, Dürr HH, Dekkers ALM, Hartmann J (2009) Global patterns of dissolved silica export to the coastal zone: Results from a spatially explicit global model. Glob Biogeochem Cycles 23:GB0A02

Blecker SW, McCulley RL, Chadwick OA, Kelly EF (2006) Biologic cycling of silica across a grassland bioclimosequence. Glob Biogeochem Cycles 20:GB3023

Blöthe JH, Korup O (2013) Millennial lag times in the Himalayan sediment routing system. Earth Plan Sci Lett 382:38-46

Bluth GJS, Kump LR (1994) Lithologic and climatologic controls of river chemistry. Geochim Cosmochim Acta 58:2341-2359

Bootsma HA, Hecky RE, Johnson TC, Kling HJ, Mwita J (2003) Inputs, outputs, and internal cycling of silica in a large, tropical lake. J Great Lakes Res 29:121-138

Boyle JF (2007) Loss of apatite caused irreversible earlyHolocene lake acidification. Holocene 17:543-547

Bradshaw EG, Rasmussen P, Odgaard BV (2005a) Mid- to lateHolocene land-use change and lake development at Dallund So, Denmark: synthesis of multiproxy data, linking land and lake. Holocene 15:1152-1162

Bradshaw EG, Rasmussen P, Nielsen H, Anderson NJ (2005b) Mid- to late-Holocene land-use change and lake development at Dallund So, Denmark: trends in lake primary production as reflected by algal and macrophyte remains. Holocene 15:1130-1142

Bricker OP, Jones BF, Bowser CJ (2005) Mass -balance approach to interpreting weathering reactions in watershed systems. In: Drever JI (ed) Surface and ground water, weathering, and soils. Elsevier, London, pp 119-132

Brown ET (2011) Lake Malawi's response to "megadrought" terminations: sedimentary records of flooding, weathering and erosion. Palaeogeogr Palaeoclimatol Palaeoecol 303:120-125

Burrough SL, Thomas DSG, Shaw PA, Bailey RM (2007) Multiphase quaternary highstands at lake Ngami, Kalahari, northern Botswana. Palaeogeogr Palaeoclimatol Palaeoecol 253:280-299

Callender E, Granina L (1997) Geochemical mass balances of major elements in Lake Baikal. Limnol Oceanogr 42:148-155

Campy M, Meybeck M (1995) Las sédiments lacustres. In: Pourriot R, Meybeck M (eds) Limnologie générale. Masson, Paris, pp 184-226

Cardinal D, Gaillardet J, Hughes HJ, Opfergelt S, André L (2010) Contrasting silicon isotope signatures in rivers from the Congo Basin and the specific behaviour of organic-rich waters. Geophys Res Lett 37:L12403

Carey JC, Fulweiler RW (2012) The terrestrial silica pump. PLoS One 7:e52932

Chaudhuri S, Clauer N, Semhi K (2007) Plant decay as a major control of river dissolved potassium: a first estimate. Chem Geol 243:178-190
Clymans W, Struyf E, Govers G, Vandevenne F, Conley DJ (2011) Anthropogenic impact on biogenic Si pools in temperate soils. Biogeosciences 8:2281-2293

Cockerton HE, Street-Perrott FA, Leng MJ, Barker PA, Horstwood MSA, Pashley V (2013) Stable-isotope (H, O, and Si) evidence for seasonal variations in hydrology and $\mathrm{Si}$ cycling from modern waters in the Nile Basin: implications for interpreting the Quaternary record. Quatern Sci Rev 66:4-21

Cole JJ, Prairie YT, Caraco NF, McDowell WH, Tranvik LJ, Striegl RG, Duarte CM, Kortelainen P, Downing JA, Middelburg JJ, Melack J (2007) Plumbing the global carbon cycle: integrating inland waters into the terrestrial carbon budget. Ecosystems 10:171-184

Conley DJ (1997) Riverine contribution of biogenic silica to the oceanic silica budget. Limnol Oceanogr 42:774-777

Conley DJ (2002) Terrestrial ecosystems and the global biogeochemical silica cycle. Glob Biogeochem Cycles 16:1121

Conley DJ, Schelske CL (1993) Potential role of sponge spicules in influencing the silicon biogeochemistry of Florida lakes. Can J Fish Aquat Sci 50:296-302

Conley DJ, Schelske CL (2001) Biogenic Silica. In: Smol JP, Birks HJB, Last WM (eds) Tracking environmental change using lake sediments, vol 3., Terrestrial, algal and siliceous indicatorsKluwer Academic, London, pp 281-293

Conley DJ, Schelske CL, Dempsey BG, Campbell CD (1986) Distribution of Biogenic Silica in the Surficial Sediments of Lake Michigan. Can J Earth Sci 23:1442-1449

Conley DJ, Schelske CL, Stoermer EF (1993) Modification of the biogeochemical cycle of silica with eutrophication. Mar Ecol Prog Ser 101:179-192

Conley D, Stalnacke P, Pitkanen H, Wilander A (2000) The Transport and Retention of Dissolved Silicate by Rivers in Sweden and Finland. Limnol Oceanogr 45:1850

Conley DJ, Likens GE, Buso DC, Saccone L, Bailey SW, Johnson CE (2008) Deforestation causes increased dissolved silicate losses in the Hubbard Brook Experimental Forest. Glob Change Biol 14:2548-2554

Cook P, Aldridge K, Lamontagne S, Brookes J (2010) Retention of nitrogen, phosphorus and silicon in a large semi-arid riverine lake system. Biogeochemistry 99:49-63

Cornelis JT, Titeux H, Ranger J, Delvaux B (2011) Identification and distribution of the readily soluble silicon pool in a temperate forest soil below three distinct tree species. Plant Soil 342:369-378

Cornwell JC, Banahan S (1992) A silicon budget for an Alaskan arctic lake. Hydrobiologia 240:37-44

De La Rocha CL (2006) Opal-based isotopic proxies of paleoenvironmental conditions. Glob Biogeochem Cycles 20:GB4S09

De La Rocha CL, Bickle MJ (2005) Sensitivity of silicon isotopes to whole-ocean changes in the silica cycle. Mar Geol 217:267-282

De La Rocha CL, Brzezinski MA, DeNiro MJ (1997) Fractionation of silicon isotopes by marine diatoms during biogenic silica formation. Geochim Cosmochim Acta 61:5051-5056

De La Rocha CL, Brzezinski MA, DeNiro MJ, Shemesh A (1998) Silicon-isotope composition of diatoms as an indicator of past oceanic change. Nature 395:680-683 
De la Rocha CL, Brzezinski MA, DeNiro MJ (2000) A first look at the distribution of the stable isotopes of silicon in natural waters. Geochim Cosmochim Acta 64:2467-2477

Dean WE (1999) The carbon cycle and biogeochemical dynamics in lake sediments. J Paleolimnol 21:375-393

Derry LA, Kurtz AC, Ziegler K, Chadwick OA (2005) Biological control of terrestrial silica cycling and export fluxes to watersheds. Nature 433:728-731

Dickson EL (1975) Silica budget for lough-neagh 1970-1972. Freshw Biol 5:1-12

Dillon PJ, Evans HE (1993) A comparison of phosphorus retention in lakes determined from mass balance and sediment core calculations. Water Res 27:659-668

Dillon PJ, Evans HE (2001) Comparison of iron accumulation in lakes using sediment core and mass balance calculations. Sci Total Environ 266:211-219

Ding T, Wan D, Wang C, Zhang F (2004) Silicon isotope compositions of dissolved silicon and suspended matter in the Yangtze River, China. Geochim Cosmochim Acta 68:205-216

Ding TP, Gao JF, Tian SH, Wang HB, Li M (2011) Silicon isotopic composition of dissolved silicon and suspended particulate matter in the Yellow River, China, with implications for the global silicon cycle. Geochim Cosmochim Acta 75:6672-6689

Downing JA, Duarte CM (2009) Abundance and size distribution of lakes, ponds and impoundments. In: Likens GE (ed) Encyclopedia of inland waters. Elsevier, Oxford, pp 469-478

Downing JA, Prairie YT, Cole JJ, Duarte CM, Tranvik LJ, Striegl RG, McDowell WH, Kortelainen P, Caraco NF, Melack JM, Middelburg JJ (2006) The global abundance and size distribution of lakes, ponds, and impoundments. Limnol Oceanogr 51:2388-2397

Durr HH, Meybeck M, Hartmann J, Laruelle GG, Roubeix V (2011) Global spatial distribution of natural riverine silica inputs to the coastal zone. Biogeosciences 8:597-620

Dürr HH, Meybeck M, Dürr SH (2005) Lithologic composition of the Earth's continental surfaces derived from a new digital map emphasizing riverine material transfer. Glob Biogeochem Cycles 19:GB4S10

Egan KE, Rickaby REM, Hendry KR, Halliday AN (2013) Opening the gateways for diatoms primes Earth for Antarctic glaciation. Earth Plan Sci Lett 375:34-43

Egge JK, Asknes DL (1992) Silicate as regulating nutrient in phytoplankton competition. Mar Ecol Prog Ser 83:281-289

Einsele G, Yan JP, Hinderer M (2001) Atmospheric carbon burial in modern lake basins and its significance for the global carbon budget. Glob Planet Change 30:167-195

Emoto M, Akagi T, Takahashi K (2013) Determination of elemental composition of diatom opal and its implication on the geochemical cycle in the Oceans. Japan Geoscience Union Meeting 2013. Japan Geoscience Union, Chiba, Japan.

Englund G, Eriksson H, Nilsson MB (2013) The birth and death of lakes on young landscapes. Geophys Res Lett 40:1340-1344

Engstrom DR, Fritz SC, Almendinger JE, Juggins S (2000) Chemical and biological trends during lake evolution in recently deglaciated terrain. Nature 408:161-166
Engstrom E, Rodushkin I, Ingri J, Baxter DC, Ecke F, Osterlund H, Ohlander B (2010) Temporal isotopic variations of dissolved silicon in a pristine boreal river. Chem Geol 271:142-152

Epstein E (1999) Silicon. Ann Rev Plant Physiol Plant Mol Biol 50:641-664

Fekete BM, Vörösmarty CJ, Grabs W (2002) High-resolution fields of global runoff combining observed river discharge and simulated water balances. Glob Biogeochem Cycles 16:1042

Fontorbe G, De La Rocha CL, Chapman HJ, Bickle MJ (2013) The silicon isotopic composition of the Ganges and its tributaries. Earth Plan Sci Lett 381:21-30

Fortin MC, Gajewski K (2009) Assessing the use of sediment organic, carbonate and biogenic silica content as indicators of environmental conditions in Arctic lakes. Polar Biol 32:985-998

Friedl G, Teodoru C, Wehrli B (2004) Is the iron gate I reservoir on the danube river a sink for dissolved silica? Biogeochemistry 68:21-32

Fritz SC, Anderson NJ (2013) The relative influences of climate and catchment processes on Holocene lake development in glaciated regions. J Paleolimnol 49:349-362

Gaillardet J, Dupre B, Louvat P, Allegre CJ (1999) Global silicate weathering and $\mathrm{CO} 2$ consumption rates deduced from the chemistry of large rivers. Chem Geol 159:3-30

Garnier J, Leporcq B, Sanchez N, Philippon X (1999) Biogeochemical mass-balances $(\mathrm{C}, \mathrm{N}, \mathrm{P}, \mathrm{Si})$ in three large reservoirs of the Seine Basin (France). Biogeochemistry 47:119-146

Garrels RM, Mackenzie FT (1967) Origin of the chemical compositions of some springs and lakes. Equilibrium concepts in natural water systems. American Chemical Society, pp. 222-242

Georg RB, Reynolds BC, Frank M, Halliday AN (2006) Mechanisms controlling the silicon isotopic compositions of river waters. Earth Plan Sci Lett 249:290-306

Georg RB, Reynolds BC, West AJ, Burton KW, Halliday AN (2007) Silicon isotope variations accompanying basalt weathering in Iceland. Earth Plan Sci Lett 261:476-490

Georg RB, West AJ, Basu AR, Halliday AN (2009) Silicon fluxes and isotope composition of direct groundwater discharge into the Bay of Bengal and the effect on the global ocean silicon isotope budget. Earth Plan Sci Lett 283:67-74

Gerard F, Mayer KU, Hodson MJ, Ranger J (2008) Modelling the biogeochemical cycle of silicon in soils: application to a temperate forest ecosystem. Geochim Cosmochim Acta 72:741-758

Goto N, Iwata T, Akatsuka T, Ishikawa M, Kihira M, Azumi H, Anbutsu K, Mitamura O (2007) Environmental factors which influence the sink of silica in the limnetic system of the large monomictic Lake Biwa and its watershed in Japan. Biogeochemistry 84:285-295

Goudie AS, Viles HA (2012) Weathering and the global carbon cycle: geomorphological perspectives. Earth Sci Rev 113:59-71

Harrison JA, Bouwman AF, Mayorga E, Seitzinger S (2010) Magnitudes and sources of dissolved inorganic phosphorus inputs to surface fresh waters and the coastal zone: a new global model. Glob Biogeochem Cycles 24:GB1003 
Harrison JA, Frings PJ, Beusen AHW, Conley DJ, McCrackin ML (2012) Global importance, patterns, and controls of dissolved silica retention in lakes and reservoirs. Glob Biogeochem Cycles 26:GB2037

Hay WW (1998) Detrital sediment fluxes from continents to oceans. Chem Geol 145:287-323

Hecky RE, Kling HJ, Brunskill GJ (1986) Seasonality of phytoplankton in relation to silicon cycling and interstitial water circulation in large, shallow lakes of central Canada. Hydrobiologia 138:117-126

Hewawasam T, von Blanckenburg F, Bouchez J, Dixon JL, Schuessler JA, Maekeler R (2013) Slow advance of the weathering front during deep, supply-limited saprolite formation in the tropical Highlands of Sri Lanka. Geochim Cosmochim Acta 118:202-230

Hijmans RJ, Cameron SE, Parra JL, Jones PG, Jarvis A (2005) Very high resolution interpolated climate surfaces for global land areas. Int J Climatol 25:1965-1978

Hilley GE, Porder S (2008) A framework for predicting global silicate weathering and $\mathrm{CO} 2$ drawdown rates over geologic time-scales. Proc Natl Acad Sci USA 105:16855-16859

Hilton J (1985) A conceptual-framework for predicting the occurrence of sediment focusing and sediment redistribution in small lakes. Limnol Oceanogr 30:1131-1143

Hinderer M (2012) From gullies to mountain belts: a review of sediment budgets at various scales. Sed Geol 280:21-59

Hinderer M, Einsele G (2001) The world's large lake basins as denudation-accumulation systems and implications for their lifetimes. J Paleolimnol 26:355-372

Hodder KR, Desloges JR, Gilbert R (2006) Pattern and timing of sediment infill at glacier-fed Mud Lake: implications for late-glacial and Holocene environments in the Monashee Mountain region of British Columbia, Canada. Holocene 16:705-716

Hofmann A, Roussy D, Filella M (2002) Dissolved silica budget in the North basin of Lake Lugano. Chem Geol 182: $35-55$

Houser J, Bierman D, Burdis R, Soeken-Gittinger L (2010) Longitudinal trends and discontinuities in nutrients, chlorophyll, and suspended solids in the Upper Mississippi River: implications for transport, processing, and export by large rivers. Hydrobiologia 651:127-144

Hughes HJ, Bouillon S, André L, Cardinal D (2012) The effects of weathering variability and anthropogenic pressures upon silicon cycling in an intertropical watershed (Tana River, Kenya). Chem Geol 308-309:18-25

Hughes HJ, Sondag F, Santos RV, André L, Cardinal D (2013) The riverine silicon isotope composition of the Amazon Basin. Geochim Cosmochim Acta 121:637-651

Humborg C, Pastuszak M, Aigars J, Siegmund H, Morth CM, Ittekkot V (2006) Decreased silica land-sea fluxes through damming in the Baltic Sea catchment-significance of particle trapping and hydrological alterations. Biogeochemistry 77:265-281

Humborg C, Smedberg E, Medina MR, Morth C-M (2008) Changes in dissolved silicate loads to the Baltic Sea-The effects of lakes and reservoirs. J Mar Syst 73:223-235

Humphries MS, Kindness A, Ellery WN, Hughes JC (2010) Sediment geochemistry, mineral precipitation and clay neoformation on the Mkuze River floodplain, South Africa. Geoderma 157:15-26
Humphries M, Kindness A, Ellery W, Hughes J (2011) Water chemistry and effect of evapotranspiration on chemical sedimentation on the Mkuze River floodplain, South Africa. J Arid Environ 75:555-565

Hutchinson GE (1957) A treatise on limnology vol 1: Geography, Physics and Chemistry. Wiley, Hoboken

Ingall ED, Diaz JM, Longo AF, Oakes M, Finney L, Vogt S, Lai B, Yager PL, Twining BS, Brandes JA (2013) Role of biogenic silica in the removal of iron from the Antarctic seas. Nat Commun 4

Ittekkot V, Unger D, Humborg C, Tac An N (2006) The perturbed silicon cycle. In: Ittekkot V, Unger D, Humborg C, Tac An N (eds.), The silicon cycle: human perturbations and impacts on aquatic systems. Island Press, London

Jeandel C, Oelkers EH (2013) Revisiting land to ocean fluxes. Mineral Mag 77:1381

Jeffries DS, Semkin RG, Neureuther R, Seymour M (1988) Ion mass budgets for lakes in the turkey lakes watershed, June 1981-May 1983. Can J Fish Aquat Sci 45:s47-s58

Jeppesen E, Jensen JP, Jensen C, Faafeng B, Hessen DO, Sondergaard M, Lauridsen T, Brettum P, Christoffersen K (2003a) The impact of nutrient state and lake depth on topdown control in the pelagic zone of lakes: a study of 466 lakes from the temperate zone to the arctic. Ecosystems 6:313-325

Jeppesen E, Jensen JP, Lauridsen TL, Amsinck SL, Christoffersen K, Sondergaard M, Mitchell SF (2003b) Sub-fossils of cladocerans in the surface sediment of 135 lakes as proxies for community structure of zooplankton, fish abundance and lake temperature. Hydrobiologia 491:321-330

Johnson TC, Eisenreich SJ (1979) Silica in Lake-SuperiorMass Balance Considerations and a Model for DynamicResponse to Eutrophication. Geochim Cosmochim Acta 43:77-91

Johnson TC, Kelts K, Odada E (2000) The holocene history of lake victoria. AMBIO 29:2-11

Kameník J, Mizera J, Řanda Z (2013) Chemical composition of plant silica phytoliths. Environ Chem Lett 11:189-195

Kelly VJ (2001) Influence of reservoirs on solute transport: a regional-scale approach. Hydrol Process 15:1227-1249

Koszelnik P, Tomaszek JA (2008) Dissolved silica retention and its impact on eutrophication in a complex of mountain reservoirs. Water Air Soil Pollut 189:189-198

Krivtsov V, Bellinger EG, Sigee DC (2000) Changes in the elemental composition of Asterionella formosa during the diatom spring bloom. J Plankton Res 22:169-184

Kump LR, Brantley SL, Arthur MA (2000) Chemical, weathering, atmospheric CO2, and climate. Ann Rev Earth Planet Sci 28:611-667

Kurtz AC, Derry LA, Chadwick OA (2002) Germanium-silicon fractionation in the weathering environment. Geochim Cosmochim Acta 66:1525-1537

Laruelle GG, Roubeix V, Sferratore A, Brodherr B, Ciuffa D, Conley DJ, Dürr HH, Garnier J, Lancelot C, Thi Le Phuong Q, Meunier JD, Meybeck M, Michalopoulos P, Moriceau B, Ní Longphuirt S, Loucaides S, Papush L, Presti M, Ragueneau O, Regnier P, Saccone L, Slomp CP, Spiteri C, Van Cappellen P (2009) Anthropogenic perturbations of the silicon cycle at the global scale: key role of the landocean transition. Glob Biogeochem Cycles 23:4031 
Lehner B, Doll P (2004) Development and validation of a global database of lakes, reservoirs and wetlands. J Hydrol 296:1-22

Lehner B, Liermann CR, Revenga C, Vörösmarty C, Fekete B, Crouzet P, Döll P, Endejan M, Frenken K, Magome J, Nilsson C, Robertson JC, Rödel R, Sindorf N, Wisser D (2011) High-resolution mapping of the world's reservoirs and dams for sustainable river-flow management. Front Ecol Environ 9:494-502

Lenton TM, Britton C (2006) Enhanced carbonate and silicate weathering accelerates recovery from fossil fuel $\mathrm{CO} 2$ perturbations. Glob Biogeochem Cycles 20:3009

Lewis WM (2011) Global primary production of lakes: 19th Baldi Memorial Lecture. Inland Waters 1:1-28

Likens GE, Davis MB (1975) Post-glacial history of Mirror Lake and its watershed in New Hampshire, USA: an initial report. Verhandlungen Internationale der Vereinigung die Limnologie 19:982-993

Likens GE, Eaton JS, Johnson NM, Pierce RS (1985) Mirror Lake-physical and chemical characteristics e: flux and balance of water and chemicals. In: Likens GE (ed) An ecosystem approach to aquatic ecology: mirror lake and its environment. Springer, New York, pp 135-155

Loucaides S, Cappellen P, Roubeix V, Moriceau B, Ragueneau O (2012) Controls on the recycling and preservation of biogenic silica from biomineralization to burial. Silicon 4:7-22

Lupker M, France-Lanord C, Galy V, Lavé J, Gaillardet J, Gajurel AP, Guilmette C, Rahman M, Singh SK, Sinha R (2012) Predominant floodplain over mountain weathering of Himalayan sediments (Ganga basin). Geochim Cosmochim Acta 84:410-432

Mackay EB, Jones ID, Folkard AM, Barker P (2012) Contribution of sediment focussing to heterogeneity of organic carbon and phosphorus burial in small lakes. Freshw Biol 57:290-304

McGlue MM, Ellis GS, Cohen AS, Swarzenski PW (2012) Playa-lake sedimentation and organic matter accumulation in an Andean piggyback basin: the recent record from the Cuenca de Pozuelos, North-west Argentina. Sedimentology 59:1237-1256

Meade RH (1988) Movement and storage of sediment in river systems. In: Lerman A, Meybeck M (eds) Physical and chemical weathering in geochemical cycles. Kluwer, Dordecht, pp 165-180

Melzer SE, Chadwick OA, Hartshorn AS, Khomo LM, Knapp AK, Kelly EF (2012) Lithologic controls on biogenic silica cycling in South African savanna ecosystems. Biogeochemistry 108:317-334

Métivier and Gaudemer (1999) Stability of output fluxes of large rivers in South and East Asia during the last 2 million years: implications on floodplain processes. Basin Res 11:293-303

Meybeck M, Vörösmarty C (2005) Fluvial filtering of land-toocean fluxes: from natural Holocene variations to Anthropocene. CR Geosci 337:107-123

Mills B, Watson AJ, Goldblatt C, Boyle R, Lenton TM (2011) Timing of Neoproterozoic glaciations linked to transportlimited global weathering. Nat Geosci 4:861-864

Mortlock RA, Froelich PN (1987) Continental weathering of germanium-ge/si in the global river discharge. Geochim Cosmochim Acta 51:2075-2082
Mulholland PJ, Elwood JW (1982) The role of lake and reservoir sediments as sinks in the perturbed global carbon-cycle. Tellus 34:490-499

Muvundja FA, Pasche N, Bugenyi FWB, Isumbisho M, Muller B, Namugize JN, Rinta P, Schmid M, Stierli R, Wuest A (2009) Balancing nutrient inputs to Lake Kivu. J Great Lakes Res 35:406-418

Nuester J, Vogt S, Twining BS (2012) Localization of iron within centric diatoms of the genus Thalassiosira. J Phycol 48:626-634

Nürnberg GK, Dillon PJ (1993) Iron Budgets in Temperate Lakes. Can J Fish Aquat Sci 50:1728-1737

Odgaard B (1993) Wind-determined sediment distribution and Holocene sediment yield in a small, Danish, kettle lake. J Paleolimnol 8:3-13

Opfergelt S, Burton KW, von Pogge Strandmann PAE, Gislason SR, Halliday AN (2013) Riverine silicon isotope variations in glaciated basaltic terrains: implications for the $\mathrm{Si}$ delivery to the ocean over glacial-interglacial intervals. Earth Plan Sci Lett 369-370:211-219

Phillips JD (2005) Weathering instability and landscape evolution. Geomorphology 67:255-272

Phillips JD (2010) The convenient fiction of steady-state soil thickness. Geoderma 156:389-398

Pokrovsky OS, Reynolds BC, Prokushkin AS, Schott J, Viers J (2013) Silicon isotope variations in Central Siberian rivers during basalt weathering in permafrost-dominated larch forests. Chem Geol 355:103-116

Pound MJ, Tindall J, Pickering SJ, Haywood AM, Dowsett HJ, Salzmann U (2013) Late Pliocene lakes and soils: a datamodel comparison for the analysis of climate feedbacks in a warmer world. Clim Past Discuss 9:3175-3207

Prokopenko AA, Kuzmin MI, Wlliams DF, Gelety VF, Kalmychkov GV, Gvozdkov AN, Solotchin PA (2005) Basinwide sedimentation changes and deglacial lake-level rise in the Hovsgol basin, NW Mongolia. Quatern Int 136: 59-69

Rodysill J, Russell J, Bijaksana S, Brown E, Safiuddin L, Eggermont H (2012) A paleolimnological record of rainfall and drought from East Java, Indonesia during the last 1,400 years. J Paleolimnol 47:125-139

Rosen P, Hall R, Korsman T, Renberg I (2000) Diatom transferfunctions for quantifying past air temperature, $\mathrm{pH}$ and total organic carbon concentration from lakes in northern Sweden. J Paleolimnol 24:109-123

Rosen P, Vogel H, Cunningham L, Reuss N, Conley DJ, Persson $P$ (2010) Fourier transform infrared spectroscopy, a new method for rapid determination of total organic and inorganic carbon and biogenic silica concentration in lake sediments. J Paleolimnol 43:247-259

Rosenmeier MF, Brenner M, Kenney WF, Whitmore TJ, Taylor CM (2004) Recent eutrophication in the Southern Basin of Lake Peten Itza, Guatemala: human impact on a large tropical lake. Hydrobiologia 511:161-172

Saccone L, Conley DJ, Sauer D (2006) Methodologies for amorphous silica analysis. J Geochem Explor 88:235-238

Schelske CL (1985) Biogeochemical silica mass balances in lake-michigan and lake-superior. Biogeochemistry 1:197-218

Schilder J, Bastviken D, van Hardenbroek M, Kankaala P, Rinta P, Stötter T, Heiri O (2013) Spatial heterogeneity and lake 
morphology affect diffusive greenhouse gas emission estimates of lakes. Geophys Res Lett 40:GL057669

Siever R (1991) Silica in the oceans: biological-geochemical interplay. In: Schneider SH, Boston P (eds) Scientists on gaia. MIT Press, Cambridge

Siever R (1992) The silica cycle in the Precambrian. Geochim Cosmochim Acta 56:3265-3272

Sommer M, Jochheim H, Höhn A, Breuer J, Zagorski Z, Busse J, Barkusky D, Meier K, Puppe D, Wanner M, Kaczorek D (2013) Si cycling in a forest biogeosystem-the importance of transient state biogenic Si pools. Biogeosciences 10:4991-5007

Stager JC, Johnson TC (2000) A 12,400 C-14 year offshore diatom record from east central Lake Victoria, East Africa. J Paleolimnol 23:373-383

Stallard RF (1998) Terrestrial sedimentation and the carbon cycle: coupling weathering and erosion to carbon burial. Glob Biogeochem Cycles 12:231-257

Stewart KA, Lamoureux SF, Finney BP (2008) Multiple ecological and hydrological changes recorded in varved sediments from Sanagak Lake, Nunavut, Canada. J Paleolimnol 40:217-233

Stone EL, Comerford N (1994) Plant and animal activity below the solum. Whole Regolith Pedol:57-74

Street-Perrott FA, Barker PA, Leng MJ, Sloane HJ, Wooller MJ, Ficken KJ, Swain DL (2008) Towards an understanding of late Quaternary variations in the continental biogeochemical cycle of silicon: multi-isotope and sediment-flux data for Lake Rutundu, Mt Kenya, East Africa, since $38 \mathrm{ka} \mathrm{BP.}$ J Quat Sci 23:375-387

Strickland JDH, Parsons TR (1968) Determination of reactive silicate. A practical handbook of seawater analysis, Fisheries Research Board of Canada, pp. 65-70

Struyf E, Conley DJ (2012) Emerging understanding of the ecosystem silica filter. Biogeochemistry 107:9-18

Struyf E, Temmerman S, Meire P (2007) Dynamics of biogenic $\mathrm{Si}$ in freshwater tidal marshes: Si regeneration and retention in marsh sediments (Scheldt estuary). Biogeochemistry $82: 41-53$

Struyf E, Smis A, Van Damme S, Meire P, Conley D (2009a) The global biogeochemical silicon cycle. Silicon $1: 207-213$

Struyf E, Opdekamp W, Backx H, Jacobs S, Conley DJ, Meire P (2009b) Vegetation and proximity to the river control amorphous silica storage in a riparian wetland (Biebrza National Park, Poland). Biogeosciences 6:623-631

Struyf E, Smis A, Van Damme S, Garnier J, Govers G, Van Wesemael B, Conley DJ, Batelaan O, Frot E, Clymans W, Vandevenne F, Lancelot C, Goos P, Meire P (2010a) Historical land use change has lowered terrestrial silica mobilization. Nat Commun 1:129

Struyf E, Mörth C-M, Humborg C, Conley DJ (2010b) An enormous amorphous silica stock in boreal wetlands. J Geophy Res 115:G04008
Syvitski JPM, Vorosmarty CJ, Kettner AJ, Green P (2005) Impact of humans on the flux of terrestrial sediment to the global coastal ocean. Science 308:376-380

Teodoru C, Wehrli B (2005) Retention of sediments and nutrients in the Iron Gate I Reservoir on the Danube River. Biogeochemistry 76:539-565

Tranter M (2005) Geochemical weathering in glacial and proglacial environments. In: Drever JI (ed) Surface and ground water, weathering, and soils. Elsevier, London, pp 189-205

Tranvik LJ, Downing JA, Cotner JB, Loiselle SA, Striegl RG, Ballatore TJ, Dillon P, Finlay K, Fortino K, Knoll LB, Kortelainen PL, Kutser T, Larsen S, Laurion I, Leech DM, McCallister SL, McKnight DM, Melack JM, Overholt E, Porter JA, Prairie Y, Renwick WH, Roland F, Sherman BS, Schindler DW, Sobek S, Tremblay A, Vanni MJ, Verschoor AM, von Wachenfeldt E, Weyhenmeyer GA (2009) Lakes and reservoirs as regulators of carbon cycling and climate. Limnol Oceanogr 54:2298-2314

Tréguer PJ, De La Rocha CL (2013) The world ocean silica cycle. Ann Rev Mar Sci 5:447-501

Trimble SW (1983) A sediment budget for Coon Creek basin in the Driftless Area, Wisconsin, 1853-1977. Am J Sci 283:454-474

Triplett LD, Engstrom DR, Conley DJ, Schellhaass SM (2008) Silica fluxes and trapping in two contrasting natural impoundments of the upper Mississippi River. Biogeochemistry 87:217-230

Tysmans DJJ, Löhr AJ, Kroeze C, Ivens WPMF, van Wijnen J (2013) Spatial and temporal variability of nutrient retention in river basins: a global inventory. Ecol Ind 34:607-615

Vance D, Teagle DAH, Foster GL (2009) Variable Quaternary chemical weathering fluxes and imbalances in marine geochemical budgets. Nature 458:493-496

Wallace AR (2003) Regional geologic setting of late cenozoic lacustrine diatomite deposits, great basin and surrounding region: overview and plans for investigation. US Department of the Interior, US Geological Survey, Denver

Wang F, Yu Y, Liu C, Wang B, Wang Y, Guan J, Mei H (2010) Dissolved silicate retention and transport in cascade reservoirs in Karst area, Southwest China. Sci Total Environ 408:1667-1675

Welch HE, Legault JA (1986) Precipitation chemistry and chemical limnology of fertilized and natural lakes at Saqvaqjuac, NWT. Can J Fish Aquat Sci 43:1104-1134

White AF, Blum AE (1995) Effects of climate on chemicalweathering in watersheds. Geochim Cosmochim Acta 59:1729-1747

Yool A, Tyrrell T (2003) Role of diatoms in regulating the ocean's silicon cycle. Global Biogeochem Cycles 17:1103

Ziegler K, Chadwick OA, Brzezinski MA, Kelly EF (2005) Natural variations of $\delta 30 \mathrm{Si}$ ratios during progressive basalt weathering, Hawaiian Islands. Geochim Cosmochim Acta 69:4597-4610 